\title{
Radiocarbon analysis of elemental and organic carbon in Switzerland during winter-smog episodes from 2008 to 2012 - Part 1: Source apportionment and spatial variability
}

\author{
P. Zotter ${ }^{1}$, V. G. Ciobanu ${ }^{1, *}$, Y. L. Zhang ${ }^{1,2,3,4,{ }^{* *}, \text { I. El-Haddad }}{ }^{1}$, M. Macchia ${ }^{5}$, K. R. Daellenbach ${ }^{1}$, G. A. Salazar ${ }^{2,3}$, \\ R.-J. Huang ${ }^{1}$, L. Wacker $^{6}$, C. Hueglin ${ }^{7}$, A. Piazzalunga ${ }^{8}$, P. Fermo ${ }^{9}$, M. Schwikowski ${ }^{2,3,4}$, U. Baltensperger ${ }^{1}$, \\ S. Szidat ${ }^{2,3}$, and A. S. H. Prévôt ${ }^{1}$ \\ ${ }^{1}$ Laboratory of Atmospheric Chemistry, Paul Scherrer Institute (PSI), 5232 Villigen PSI, Switzerland \\ ${ }^{2}$ Department of Chemistry and Biochemistry, University of Bern, Bern, Switzerland \\ ${ }^{3}$ Oeschger Centre for Climate Change Research, University of Bern, Bern, Switzerland \\ ${ }^{4}$ Laboratory of Radiochemistry and Environmental Chemistry, Paul Scherrer Institute (PSI), 5232 Villigen PSI, Switzerland \\ ${ }^{5}$ CEDAD-Department of Engineering for Innovation, University of Salento, Lecce, Italy \\ ${ }^{6}$ Laboratory of Ion Beam Physics, ETH Hönggerberg, Zürich, Switzerland \\ ${ }^{7}$ Laboratory for Air Pollution and Environmental Technology, Swiss Federal Laboratories for Materials Science and \\ Technology (Empa), Überlandstrasse 129, 8600 Dübendorf, Switzerland \\ ${ }^{8}$ University of Milano Bicocca, Department of Earth and Environmental Sciences, 20126 Milano, Italy \\ ${ }^{9}$ Department of Chemistry, University of Milano, 20133 Milano, Italy \\ * now at: Centre for Ice and Climate, Niels Bohr Institute, University of Copenhagen, Copenhagen, Denmark \\ *** now at: Yale-NUIST Center on Atmospheric Environmental, Nanjing University of Information Science and Technology, \\ Nanjing, Jiangsu 210044, China
}

Correspondence to: A. S. H. Prévôt (andre.prevot@psi.ch)

Received: 6 May 2014 - Published in Atmos. Chem. Phys. Discuss.: 13 June 2014

Revised: 4 September 2014 - Accepted: 21 October 2014 - Published: 19 December 2014

\begin{abstract}
While several studies have investigated wintertime air pollution with a wide range of concentration levels, hardly any results are available for longer time periods covering several winter-smog episodes at various locations; e.g., often only a few weeks from a single winter are investigated. Here, we present source apportionment results of winter-smog episodes from 16 air pollution monitoring stations across Switzerland from five consecutive winters. Radiocarbon $\left({ }^{14} \mathrm{C}\right)$ analyses of the elemental (EC) and organic (OC) carbon fractions, as well as levoglucosan, major water-soluble ionic species and gas-phase pollutant measurements were used to characterize the different sources of $\mathrm{PM}_{10}$. The most important contributions to $\mathrm{PM}_{10}$ during winter-smog episodes in Switzerland were on average the secondary inorganic constituents (sum of nitrate, sulfate and ammonium $=41 \pm 15 \%)$ followed by organic matter $(\mathrm{OM})(34 \pm 13 \%)$ and EC $(5 \pm 2 \%)$. The non-fossil frac-
\end{abstract}

tions of $\mathrm{OC}\left(f_{\mathrm{NF}, \mathrm{OC}}\right)$ ranged on average from 69 to 85 and 80 to $95 \%$ for stations north and south of the Alps, respectively, showing that traffic contributes on average only up to $\sim 30 \%$ to OC. The non-fossil fraction of EC $\left(f_{\mathrm{NF}, \mathrm{EC}}\right)$, entirely attributable to primary wood burning, was on average $42 \pm 13$ and $49 \pm 15 \%$ for north and south of the Alps, respectively. While a high correlation was observed between fossil EC and nitrogen oxides, both primarily emitted by traffic, these species did not significantly correlate with fossil $\mathrm{OC}\left(\mathrm{OC}_{\mathrm{F}}\right)$, which seems to suggest that a considerable amount of $\mathrm{OC}_{\mathrm{F}}$ is secondary, from fossil precursors. Elevated $f_{\mathrm{NF}, \mathrm{EC}}$ and $f_{\mathrm{NF}, \mathrm{OC}}$ values and the high correlation of the latter with other wood burning markers, including levoglucosan and water soluble potassium $\left(\mathrm{K}^{+}\right)$indicate that residential wood burning is the major source of carbonaceous aerosols during winter-smog episodes in Switzerland. The inspection of the non-fossil OC and EC levels and the relation with 
levoglucosan and water-soluble $\mathrm{K}^{+}$shows different ratios for stations north and south of the Alps (most likely because of differences in burning technologies) for these two regions in Switzerland.

\section{Introduction}

Ambient particulate matter (PM) influences the Earth's climate directly by scattering and absorbing solar radiation and indirectly by modifying cloud microphysics (Pöschl, 2005; IPCC, 2013). In addition, aerosol particles also adversely affect human health as they can cause respiratory and cardiovascular diseases which can lead to increased mortality (Pope and Dockery, 2006; WHO, 2006). In Alpine regions and most parts of Switzerland elevated PM concentrations are often found during wintertime since topography (e.g., alpine valleys) and frequent thermal inversions favor the accumulation of pollutants (Gehrig and Buchmann, 2003; Ruffieux et al., 2006). Environmental pollution control strategies and policies have focused mainly on emissions from fossil fuel combustion so far (e.g., road traffic and industry). However, many recent studies have shown that wood burning emissions from domestic heating can be the dominating source of carbonaceous aerosols during the cold season, in Europe (e.g., Szidat et al., 2006, 2007; Lanz et al., 2008, 2010; Favez et al., 2010; Gilardoni et al., 2011; Harrison et al., 2012; Herich et al., 2014 and references therein). Therefore, the quantification of the fossil and non-fossil, especially wood burning, contributions to PM, particularly for days with high PM concentrations, is crucial for establishing effective mitigation strategies.

Carbonaceous particles are a major fraction of the fine aerosol $\left(\mathrm{PM}_{2.5}, \mathrm{PM}<2.5 \mu \mathrm{m}\right)$, contributing from 10 up to $90 \%$ of the PM mass (Gelencsér, 2004; Putaud et al., 2004; Jimenez et al., 2009). Carbonaceous aerosols are further classified into two sub-fractions: elemental carbon (EC) and organic carbon (OC) (Jacobson et al., 2000). EC originates from incomplete combustion of fossil and non-fossil fuels (e.g., coal, gasoline, diesel, oil and biomass), exclusively emitted directly as primary aerosol into the atmosphere. In contrast, OC may be either primary OC (POC) directly emitted into the atmosphere or secondary OC (SOC) formed in the atmosphere through the oxidation of volatile organic compounds (VOCs) from both fossil (coal combustion, industrial and vehicle emissions) and non-fossil (e.g., wood burning and biogenic emissions as well as cooking) sources (Jacobson et al., 2000; Pöschl, 2005; Hallquist et al., 2009). Among several techniques applied to identify and quantify carbonaceous aerosol sources, radiocarbon $\left({ }^{14} \mathrm{C}\right.$, halflife $=5730$ years) analysis is a quantitative tool for unambiguously distinguishing fossil and non-fossil sources. ${ }^{14} \mathrm{C}$ is completely depleted in emissions from fossil-fuel combustion, which can therefore be separated from non-fossil car- bon sources which have a similar ${ }^{14} \mathrm{C}$ signal as atmospheric carbon dioxide $\left(\mathrm{CO}_{2}\right)$ (Szidat, 2009; Heal, 2014). The most detailed information about different sources can be achieved when ${ }^{14} \mathrm{C}$ measurements are performed on OC and EC separately, since EC originates exclusively from biomass burning and fossil fuel combustion. By contrast, the apportionment of OC into these two sources using this methodology is less straightforward due to the complex primary and secondary sources of this fraction.

Radiocarbon-based source apportionment results available in the literature are often reported from measurement campaigns covering rather short periods (e.g., several days or a few months, see Hodzic et al. (2010), Minguillón et al. (2011) and Heal (2014) and references therein for a summary of several publications). Very few studies present annual or seasonal results from a full year or several seasons. For example, only two ${ }^{14} \mathrm{C}$ data sets are available covering a time period of 2 full years (Gelencsér et al., 2007; Larsen et al., 2012), while only a few studies present a yearly cycle (e.g., Huang et al., 2010; Ceburnis et al., 2011; Genberg et al., 2011; Gilardoni et al., 2011; Zhang et al., 2014) or data from two consecutive summers (Tanner et al., 2004) or winters (Glasius et al., 2011). In addition, ${ }^{14} \mathrm{C}$ results from the same time period are available simultaneously only for a limited number of stations (usually less than five, see Heal (2014) and references therein). Furthermore, only a few groups worldwide perform ${ }^{14} \mathrm{C}$ measurements of the $\mathrm{EC}$ fraction, since such analyses are still challenging and since there are still open questions concerning the optimal approach for the EC isolation for ${ }^{14} \mathrm{C}$ analysis (Zhang et al., 2012; Bernardoni et al., 2013; Szidat et al., 2013; Dusek et al., 2014). As a consequence, results of ${ }^{14} \mathrm{C}$ measurements carried out separately on EC and OC are still very scarce (see Minguillón et al. (2011) and Heal (2014) and references therein).

In this study, we present, to the best of our knowledge, for the first time ${ }^{14} \mathrm{C}$ measurements covering a time period of five years. Aerosol filter samples were collected during winter-smog episodes (days exceeding the Swiss daily $\mathrm{PM}_{10}$ limit of $50 \mu \mathrm{g} \mathrm{m}^{-3}$ ), at 16 air pollution monitoring stations across Switzerland to provide a good spatial resolution as well as different source characteristics in various area types (e.g., urban, suburban, rural, alpine valley, traffic, background, etc.). These samples were analyzed for the ${ }^{14} \mathrm{C}$ content in $\mathrm{EC}$ and $\mathrm{OC}$, levoglucosan, and major water soluble ionic species. The duration of this project together with the large number of stations results in one of the world's largest aerosol ${ }^{14} \mathrm{C}$ data sets available. This paper is the first paper of a two-part series investigating the spatial and temporal variability in the fossil and non-fossil sources of the organic and elemental carbon during high pollution events in Switzerland. This paper presents the ${ }^{14} \mathrm{C}$-based source apportionment results of carbonaceous aerosols and investigates their spatial variability. The second paper will explore the influence of meteorological parameters on the dif- 
ferent carbonaceous components, their temporal variability and their possible trends in the last years (Zotter et al., 2014).

\section{Materials and methods}

\subsection{Aerosol sampling}

The filter samples analyzed in this study were collected at four stations of the Swiss National Air Pollution Monitoring Network NABEL and 12 stations of the Swiss Cantonal air pollution monitoring networks (EMPA, 2013; Cercl'Air, 2012). These were selected such that a good spatial distribution across Switzerland is achieved (see Fig. 1). In detail, eight stations (PAY, SOL, SIS, BAS, REI, BER, ZUR and STG) are located on the Swiss Plateau, one station each in the Rhine and Rhone valley (VAD and MAS, respectively) and one station $(\mathrm{SCH})$ in a small alpine valley in central Switzerland. Those 11 stations will be further referred to as stations "north of the Alps". In addition, five sites "south of the Alps" were selected. These include stations at the Italian border where the terrain is more open (e.g., station CHI), plus other stations enclosed within narrow valleys (e.g., stations SVI and ROV). The locations of the stations are shown in Fig. 1 and related details are listed in Table 1. Furthermore, the selection of the stations was also carried out such that the full range of different station characteristics (from urban/traffic to rural background, see Table 1) was covered.

At the selected sites, aerosols samples were collected onto quartz fiber filters (Pallflex 2500QAT-UP) for $24 \mathrm{~h}$ on a regular basis (every 2 nd or 4 th day or daily depending on the station) using high-volume samplers (Digitel DHA-80, Switzerland) operating at a flow rate of $500 \mathrm{~L} \mathrm{~min}^{-1}$ and equipped with $\mathrm{PM}_{10}$ inlets. After the sampling, filters were wrapped in aluminum foil or lint free paper, sealed in plastic bags, and stored at $-20^{\circ} \mathrm{C}$ until analysis. Filter sampling has been widely used, but well-known non-systematic artifacts due to adsorption and volatilization of semi-volatile compounds exist (Viana et al., 2006; Jacobson et al., 2000). Since a more complex sampling (e.g., using two sampling lines in parallel, one with and the other without a denuder system for volatile OC removal or using two filters in series) is not carried out at regular air pollution monitoring stations, artifacts could not be quantified. However, due to the high filter loadings in winter such sampling artifacts are not expected to have a large contribution (e.g., Viana et al. (2007) found a 5 and $7 \%$ contribution of $\mathrm{OC}$ from positive sampling artifacts for winter samples in Amsterdam and Ghent), and we assume that they will not significantly influence the results presented in this study. It should be noted that on some filters PM $_{10}$ mass was measured gravimetrically which includes weighting before and after the sampling at a relative humidity $(\mathrm{RH})$ of $50 \pm 2 \%$ and a temperature $(T)$ of $20 \pm 2{ }^{\circ} \mathrm{C}$ after conditioning for $48 \mathrm{~h}$. Since these handling steps may introduce additional artifacts and none of the samples were pre-heated to

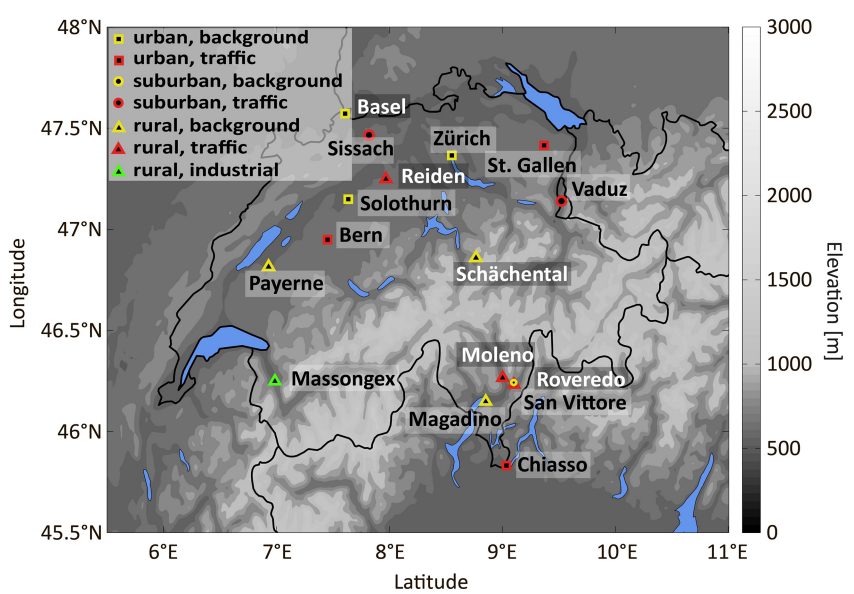

Figure 1. Location of the different stations in Switzerland investigated in this study. White labels indicate stations from which filters from only one or two winters were analyzed. For all other stations samples from four or five winters were studied.

remove any OC or EC present on the filters prior to sampling, the analysis of blank filters which were treated exactly the same way as the samples is very important. Therefore, $\sim 50$ field blank filters were collected and 34 of them were analyzed for ${ }^{14} \mathrm{C}$ in $\mathrm{OC}, 45$ for major water-soluble ionic species and 47 for OC and EC mass loading.

Every winter, 5 days with high $\mathrm{PM}_{10}$ concentrations were investigated and therefore, most of the results presented below are considered as representative for wintersmog episodes, which were the objective of our study. Winter-smog episodes in Switzerland frequently occur on days with inversions, and hence relatively shallow boundary layer heights. The days were selected such that ideally $\mathrm{PM}_{10}$ concentrations at all stations exceeded the daily limit value of $50 \mu \mathrm{g} \mathrm{m}^{-3}$. However, since meteorological conditions in Switzerland north and south of the Alps can differ strongly in winter, it was not possible to find enough days where the selection criterion was fulfilled at all stations simultaneously. Therefore, 5 identical days were chosen separately for stations south and north of the Alps. This ensures similar meteorology and the interpretability of the results in terms of spatial variations within the two regions. In addition, two to three filters per month from August 2008 to July 2009 of the urban background station ZUR were selected to cover a full yearly cycle. In total 320 aerosol filter samples were analyzed for this study. The detailed selection of all analyzed days and the distribution of $\mathrm{PM}_{10}$ concentrations on those days for every station are shown in Table S1 in the Supplement and Fig. 2, respectively.

\subsection{EC / OC measurements}

The EC and OC concentrations were measured on all samples $(n=320)$ and blanks $(n=47)$ using a thermo-optical OC / EC analyzer (Model 4L, Sunset Laboratory Inc., USA), 
Table 1. List of all stations, their classification according to the Swiss Federal Office for the Environment (FOEN), their general location in Switzerland, their abbreviations which are used later in the text, figures and tables, as well the different winter seasons from which filters from each station were analyzed.

\begin{tabular}{llllrr}
\hline Station name & Station code & General location & Station type & Altitude & Winter analyzed $^{\text {a }}$ \\
\hline Reiden-A2 & REI & north of the Alps/ & rural/highway & $510 \mathrm{~m}$ & $07 / 08$ \\
Basel-St. Johann & BAS & Swiss Plateau & urban/background & $308 \mathrm{~m}$ & $07 / 08-08 / 09$ \\
Sissach-West & SIS & & suburban/traffic & $410 \mathrm{~m}$ & $07 / 08-11 / 12$ \\
Solothurn-Altwyberhüsli & SOL & & urban/background & $502 \mathrm{~m}$ & $07 / 08-11 / 12$ \\
Payerne & PAY & & rural/background & $539 \mathrm{~m}$ & $07 / 08-11 / 12$ \\
Zürich-Kaserne & ZUR & & urban/background & $457 \mathrm{~m}$ & $07 / 08-11 / 12^{\mathrm{b}}$ \\
St.Gallen-Rorschacherstrasse & STG & & urban/traffic & $457 \mathrm{~m}$ & $07 / 08-11 / 12$ \\
Bern-Bollwerk & BER & & urban/traffic & $506 \mathrm{~m}$ & $08 / 09-12 / 13$ \\
\hline Vaduz-Austrasse & VAD & north of the Alps/ & suburban/traffic & $706 \mathrm{~m}$ & $07 / 08-11 / 12$ \\
Massongex & MAS & alpine valley & rural/industry & $452 \mathrm{~m}$ & $08 / 09-11 / 12$ \\
Schächental & rCH & rural/background & $995 \mathrm{~m}$ & $10 / 11$ \\
\hline Chiasso & CHI & south of the Alps & urban/traffic & $291 \mathrm{~m}$ & $07 / 08-11 / 12$ \\
Magadino-Cadenazzo & MAG & & rural/background & $254 \mathrm{~m}$ & $07 / 08-11 / 12$ \\
\hline Moleno-A2 & MOL & south of the Alps/ & rural/highway & $305 \mathrm{~m}$ & $07 / 08$ \\
Roveredo-Stazione & ROV & alpine valley & suburban/background & $370 \mathrm{~m}$ & $07 / 08$ \\
San-Vittore & SVI & & rural/traffic & $330 \mathrm{~m}$ & $07 / 08-11 / 12$ \\
\hline
\end{tabular}

${ }^{a} \mathrm{EC}$ and OC concentrations, ${ }^{14} \mathrm{C}$ in OC and EC were analyzed on all filters. Levoglucosan was only analyzed for all stations for the winters $2007 / 2008$ and 2008/2009. ${ }^{\text {b }}$ In addition, a yearly cycle from August 2008 to July 2009 with 2-3 samples per month was analyzed for ZUR.

which is equipped with a non-dispersive infrared (NDIR) detector. All samples were combusted following the thermaloptical transmittance method (TOT) using the EUSAAR2 temperature protocol (Cavalli et al., 2010). It should be noted here that the OC / EC determination with TOT instruments is not standardized yet and that measurements with different thermal protocols (e.g., NIOSH NIOSH, 1999; Peterson and Richards, 2002), IMPROVE (Chow et al., 1993), EUSAAR2 (Cavalli et al., 2010) may lead to discrepancies. Typically, total carbon (TC) measured with different protocols shows good agreement (within 10\%), whereas EC can differ significantly from method to method, up to $25 \%$, and for highly polluted winter samples even up to $60 \%$ (Chow et al., 2001, Schmid et al., 2001; Piazzalunga et al., 2011a). We chose the EUSAAR2 protocol since this protocol is also used by the NABEL and Cantonal air quality monitoring programs to measure OC / EC concentrations for some stations on a regular basis.

Repeated measurements were carried out for 150 samples out of the 320. A blank correction was performed using the average TC filter loading $\left(2.5 \pm 0.8 \mu \mathrm{g} \mathrm{C} \mathrm{cm}{ }^{-2}\right)$ of all measured blank filters $(n=47)$ since no systematic differences between the different stations or throughout the years were found (see Fig. S1 in the Supplement). Since EC was not detectable in any of the blank samples, the mean TC blank concentration was also used for the blank correction of OC. The average contribution of the blanks to the total filter loading was $5 \pm 2$ and $4 \pm 2 \%$ for OC and TC, respectively. The mean measurement uncertainty for $\mathrm{OC}$ and $\mathrm{TC}$ was estimated to be 7.7 and $8.1 \%$, respectively, using the variability of all samples $(n=8)$ that were measured three or four times and the variability of the blanks. The uncertainty for EC was assumed to be $25 \%$ to account for possible differences between different TOT protocols (Schmid et al., 2001).

\section{$2.3{ }^{14} \mathrm{C}$ analysis}

\subsubsection{Separation of carbonaceous particle fractions and ${ }^{14} \mathrm{C}$ analysis}

${ }^{14} \mathrm{C}$ analysis of EC and OC was carried out on all samples. ${ }^{14} \mathrm{C}$ content in the blanks was only measured for TC, since an EC loading was not found on those filters (see Sect. 2.2). In the following, we will describe the techniques and procedures of the separation of OC and $\mathrm{EC}$ for subsequent ${ }^{14} \mathrm{C}$ measurements.

OC was separated for ${ }^{14} \mathrm{C}$ analysis using the THEODORE system and the Sunset analyzer (see Szidat et al., 2004 and Zhang et al., 2012, respectively for more details). In brief, in THEODORE filter punches with a diameter of 11 to $16 \mathrm{~mm}$ were combusted at $340^{\circ} \mathrm{C}$ for $10 \mathrm{~min}$ in a pure oxygen $\left(\mathrm{O}_{2}\right)$ stream. The Sunset analyzer, connected to the trapping part of the THEODORE system, was modified such that it could be operated with pure oxygen as a carrier gas in addition to the conventionally used $\mathrm{He}$ and $\mathrm{He} / \mathrm{O}_{2}$. The temperatures and combustion times for the oxidation of $\mathrm{OC}$ to $\mathrm{CO}_{2}$ from filter punches with $0.8-1.5 \mathrm{~cm}^{2}$ in the Sunset analyzer were set to the same values as those used in the THEODORE pro- 
tocol. The evolving $\mathrm{CO}_{2}$, from the THEODORE and the Sunset analyzer, was separated from interfering reaction gases, cryo-trapped and sealed in glass ampoules for ${ }^{14} \mathrm{C}$ measurements.

The separation of EC for the ${ }^{14} \mathrm{C}$ measurement was carried out following the Swiss $4 \mathrm{~S}$ protocol as described by Zhang et al. (2012). First, water-soluble OC (WSOC) and other water-soluble components were removed by water extraction in order to minimize positive artifacts from OC charring (Piazzalunga et al., 2011a; Zhang et al., 2012). The remaining water-insoluble OC (WINSOC) was then removed by a thermal treatment in three steps. In the first two steps, $\mathrm{OC}$ was oxidized in $\mathrm{O}_{2}$ at $375^{\circ} \mathrm{C}$ for $150 \mathrm{~s}$ and then at $475^{\circ} \mathrm{C}$ for $180 \mathrm{~s}$. In the third step, $\mathrm{OC}$ was then evaporated in an inert atmosphere in helium at $450{ }^{\circ} \mathrm{C}$ for $180 \mathrm{~s}$ followed by $180 \mathrm{~s}$ at $650^{\circ} \mathrm{C}$. In the end (step four), EC was isolated by the combustion of the remaining carbonaceous material at $760{ }^{\circ} \mathrm{C}$ for $150 \mathrm{~s}$ in $\mathrm{O}_{2}$. This method was optimized to reduce biases in ${ }^{14} \mathrm{C}$ measurements of $\mathrm{EC}$ related to $\mathrm{OC}$ charring (leading to higher non-fossil $\mathrm{EC}\left(\mathrm{EC}_{\mathrm{NF}}\right)$ values) or losses of the least refractory EC (mostly from wood burning) during the WINSOC removal (in the steps one to three) as those would lead to lower $\mathrm{EC}_{\mathrm{NF}}$ fractions. Furthermore, using the Sunset analyzer for the combustion made it possible to quantify those artifacts online, since this instrument monitors the filters during the combustion with a laser. As proposed by Zhang et al. (2012) we tested the effect of different temperatures in step two and three of the thermal protocol on the EC yields and the $\mathrm{OC}$ charring for some samples from stations with contrasting sources and filter loadings (e.g., filters with high and low loading from stations with a large wood burning contribution vs. more traffic influenced stations). Charring of OC most likely occurred only at lower temperature in the steps one and two and was quantified as the difference of the maximum attenuation (ATN) and the initial ATN normalized to the initial ATN of the given thermal step. The EC yield denotes the fraction of EC remaining on the filter samples after the first three OC removal steps before the last step (step four) starts, which was used for the EC recovery for ${ }^{14} \mathrm{C}$ analysis, and is defined as the ratio between the initial ATN of the laser signal through the filter before step one of the thermal treatment and the ATN before step four. We found that the EC yield and charring did not vary significantly due to different temperatures $\left(550-700^{\circ} \mathrm{C}\right)$ in step three and therefore this temperature was set to $650^{\circ} \mathrm{C}$ as suggested by Zhang et al. (2012). In contrast, varying the temperature in step two we found 525 and $500{ }^{\circ} \mathrm{C}$ as optimal values for SVI and BER, respectively, which exhibited very high filter loadings. Higher temperatures for these two stations were necessary to assure complete removal of OC and possibly charred $\mathrm{OC}$ before the EC step (step four). For the samples from the other stations $475^{\circ} \mathrm{C}$, as suggested by Zhang et al. (2012), was found to be the optimal setting. On average $74 \pm 11 \%$ of the EC was recovered for the ${ }^{14} \mathrm{C}$ mea- surement for all samples and charred OC only contributed $5.3 \pm 4.5 \%$ to EC recovered in step four.

The ${ }^{14} \mathrm{C}$ measurement of the collected $\mathrm{CO}_{2}$ from the separated carbonaceous fractions was performed with the MIni radioCArbon DAting System, MICADAS (Synal et al., 2007) at the Swiss Federal Institute of Technology (ETH) Zürich and the Laboratory for the Analysis of Radiocarbon with AMS (LARA), University of Bern (Szidat et al., 2014), Switzerland, using a gas ion source (Ruff et al., 2007; Wacker et al., 2013), which allows direct $\mathrm{CO}_{2}$ injection after dilution with He (Ruff et al., 2010). All ${ }^{14} \mathrm{C}$ results are expressed as fraction of modern $\left(f_{\mathrm{M}}\right)$ representing the ratio of the ${ }^{14} \mathrm{C} /{ }^{12} \mathrm{C}$ content of the sample related to the isotopic ratio of the reference year 1950 (Stuiver and Polach, 1977). The $f_{\mathrm{M}}$ values were corrected for $\delta^{13} \mathrm{C}$ fractionation (Wacker et al., 2010) and for the ${ }^{14} \mathrm{C}$ decay between 1950 and the year of measurement. The uncertainty of the measured $f_{\mathrm{M}}$ values for OC and $\mathrm{EC}$ ( $f_{\mathrm{M}, \mathrm{OC}}$ and $f_{\mathrm{M}, \mathrm{EC}}$, respectively) is on average $\sim 2 \%$ for the samples presented here.

\subsubsection{Data correction and presentation}

As discussed in the following, several corrections have to be applied to the $f_{\mathrm{M}}$ values obtained from the ${ }^{14} \mathrm{C}$ measurement (see also Table 2 for a summary).

1. Blank correction: a mass-dependent blank correction is applied to the measured $f_{\mathrm{M}}$ values following an isotopic mass balance approach (Zapf et al., 2013):

$$
\begin{aligned}
f_{\mathrm{M}, \mathrm{corr}}= & \left(m \mathrm{C}_{\mathrm{sample}} \cdot f_{\mathrm{M}, \mathrm{sample}}-m \mathrm{C}_{\mathrm{blk}} \cdot f_{\mathrm{M}, \mathrm{blk}}\right) \\
& /\left(m \mathrm{C}_{\mathrm{sample}}-m \mathrm{C}_{\mathrm{blk}}\right)
\end{aligned}
$$

where $f_{\mathrm{M} \text {,corr }}$ is the blank corrected $f_{\mathrm{M}}$, and $f_{\mathrm{M} \text {, sample }}$ and $f_{\mathrm{M}, \mathrm{blk}}$ are the $f_{\mathrm{M}}$ measured for samples and blanks, respectively. $m \mathrm{C}_{\text {sample }}$ and $m \mathrm{C}_{\mathrm{blk}}$ denote the carbon mass in the samples and the blanks, respectively. Since blank filters are not available for all stations and years and since the ${ }^{14} \mathrm{C}$ results of the blanks were not systematically different (between different stations or years, see Fig. S1), the average $f_{\mathrm{M}}$ and TC values of the blanks, $0.53 \pm 0.12(n=34)$ and $2.5 \pm 0.8 \mu \mathrm{g} \mathrm{C} \mathrm{cm}^{-2}$ $(n=47)$, respectively, were considered for the correction of $f_{\mathrm{M}, \mathrm{OC}}\left(f_{\mathrm{M}, \mathrm{OC}, \mathrm{corr}}\right)$. The blank correction in-

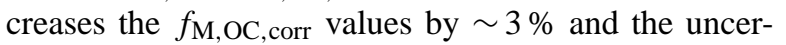
tainty (error propagation of Eq. (1)) rises to $\sim 3 \%$. No EC was detected on the blank filters (see Sect. 2.2 above); therefore no blank correction was carried out for $f_{\mathrm{M}, \mathrm{EC} \text {. }}$

2. EC yield correction: the fraction of EC, which was isolated for the ${ }^{14} \mathrm{C}$ measurement (EC yield) was on average $74 \pm 11 \%$ as shown in Sect. 2.3.1. However, Zhang et al. (2012) showed that $f_{\mathrm{M}, \mathrm{EC}}$ changes with different $\mathrm{EC}$ recoveries. They found a linear relationship between 
Table 2. Summary of the different correction steps of the ${ }^{14} \mathrm{C}$ raw data.

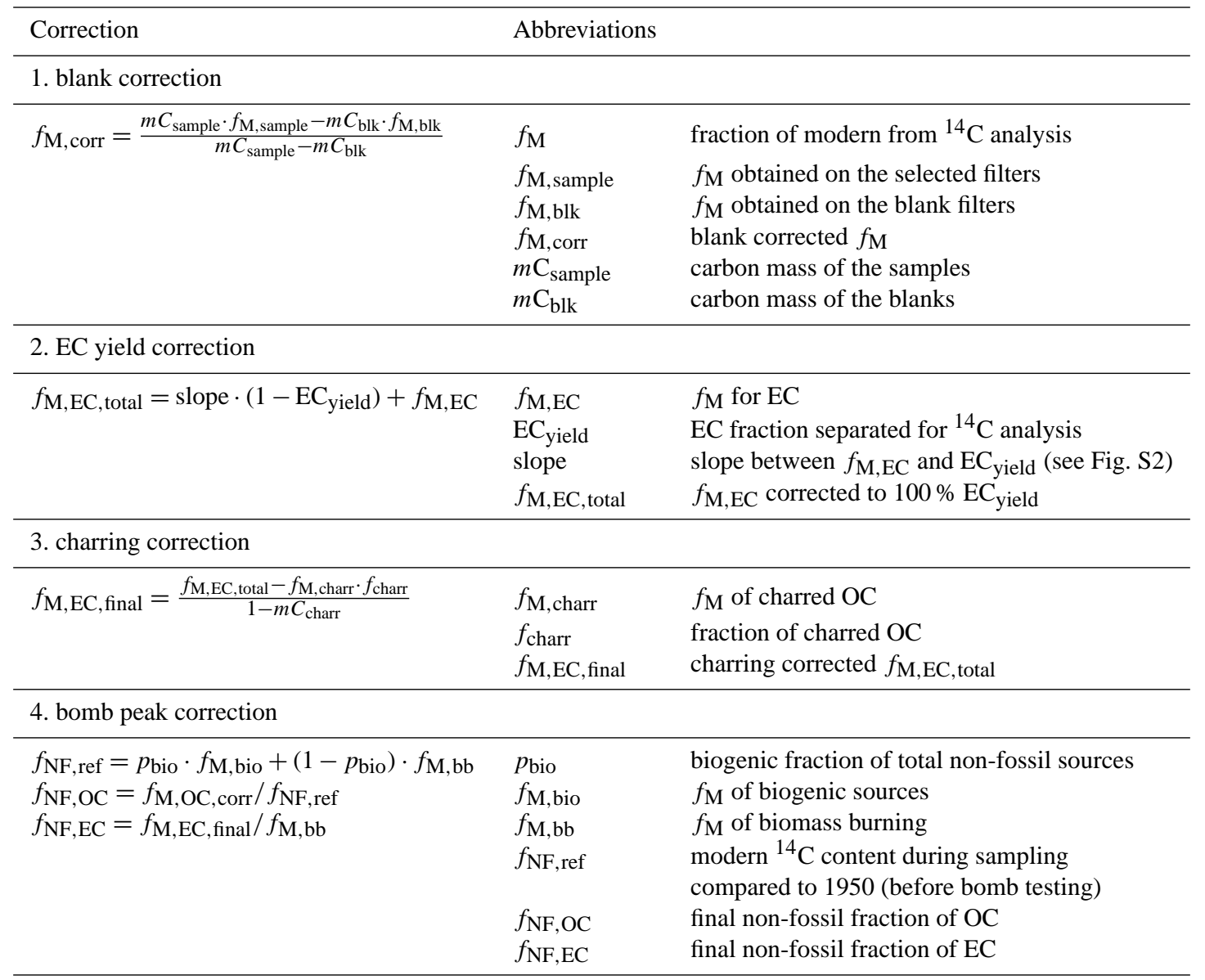

$f_{\mathrm{M} \text {,EC }}$ and the EC yield, which they used to extrapolate $f_{\mathrm{M}, \mathrm{EC}}$ to $100 \% \mathrm{EC}$ yield using the average slope $(0.31 \pm 0.1)$ from several samples $(n=5)$ in order to account for the slight underestimation of biomass burning EC caused by the EC loss during EC isolation for ${ }^{14} \mathrm{C}$ measurement (see Sect. 2.3.1 above). In this study, we also measured $f_{\mathrm{M} \text {,EC }}$ from 11 samples at different EC yields. As shown in Fig. S2 there is also a linear relationship between the EC yield and $f_{\mathrm{M} \text {,EC }}$ for the samples from this study. Even though the slopes exhibit a larger variability compared to the ones presented in Zhang et al. (2012) the average slope of all winter samples is very similar. In contrast, the slopes for the summer filters show only a very weak relationship between $f_{\mathrm{M} \text {,EC }}$ and the EC yield due to the smaller fraction of less refractory EC (mainly from biomass burning) which is removed before the $\mathrm{EC}$ isolation for the ${ }^{14} \mathrm{C}$ analysis. Beside the clear difference between samples from summer and winter, no systematic differences between different stations or years were found. Therefore, average slopes of $0.35 \pm 0.11$ and $0.07 \pm 0.03$ for winter and summer samples, respectively, were taken to correct all $f_{\mathrm{M}, \mathrm{EC}}$ values to $100 \% \mathrm{EC}$ yield $\left(f_{\mathrm{M}, \mathrm{EC}, \text { total }}\right)$ using the following equation (Zhang et al., 2012):

$f_{\mathrm{M}, \mathrm{EC}, \text { total }}=$ slope $\cdot\left(1-\mathrm{EC}_{\mathrm{yield}}\right)+f_{\mathrm{M}, \mathrm{EC}} \cdot$

The uncertainty of $f_{\mathrm{M}, \mathrm{EC} \text {, total }}$ was obtained by an error propagation of Eq. (2) using the variability of the average slopes, the measurement uncertainty of $f_{\mathrm{M}, \mathrm{EC}}$ and an assigned uncertainty of $10 \%$ for the EC yield and is on average $4.2 \%$.

3. Charring correction: approximately 50 samples exhibited OC charring contributing $>10 \%$ to EC even though the method used here for EC isolation is optimized to minimize OC charring. Therefore, the $f_{\mathrm{M}, \mathrm{EC} \text {,total }}$ values were corrected for charring $\left(f_{\mathrm{M}, \mathrm{EC}, \mathrm{final}}\right)$ using the same isotopic mass balance approach as described in Eq. (1) in which the $f_{\mathrm{M}}$ and $m \mathrm{C}$ values of the sam-

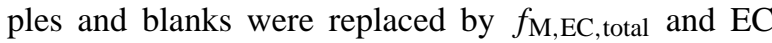
as well as the fraction ( $f_{\text {charr }}$, formed in step one and two of the thermal treatment as described in Sect. 2.3.1) and $f_{\mathrm{M}}$ of charred OC $\left(f_{\mathrm{M} \text {,charr }}\right)$. We assumed that only 
$50 \%$ of the charred $\mathrm{OC}$ contributed to the ${ }^{14} \mathrm{C}$ result of EC since some charred material was most likely removed in step three. However, since some EC could be lost in step three as well, the charred OC evaporated in step three cannot be quantified. Therefore, a high uncertainty of $33 \%$ is assigned to the fraction of charred OC which should in addition account for possible differences and variability between samples and stations. The $f_{\mathrm{M} \text {,charr }}$ was obtained from ${ }^{14} \mathrm{C}$ measurements $(n=11)$ of WINSOC from water-extracted filters released in step one and was found to be on average 0.78 . To account for possible sample-to-sample differences and variability between samples and stations, we assigned an uncertainty of 0.10 for $f_{\mathrm{M} \text {,charr }}$. The uncertainty of $f_{\mathrm{M} \text {,EC,final }}$ was on average $4.4 \%$, which is only slightly higher than for $f_{\mathrm{M}, \mathrm{EC} \text {,total }}(4.2 \%)$.

4. Bomb peak correction: samples from fossil sources are characterized by $f_{\mathrm{M}}=0$ due to the extinction of ${ }^{14} \mathrm{C}$ with a half-life of 5730 years, whereas $f_{\mathrm{M}}$ is equal to 1 for contemporary carbon sources including biogenic and biomass burning ( $f_{\mathrm{M} \text {,bio }}$ and $f_{\mathrm{M}, \mathrm{bb}}$, respectively). However, due to the thermonuclear weapon tests of the late 1950s and early 1960s the radiocarbon content of the atmosphere increased and $f_{\mathrm{M}}$ exhibit values greater than one (Levin et al., 2010). To account for this effect, the $f_{\mathrm{M}, \mathrm{OC} \text {,corr }}$ and $f_{\mathrm{M}, \mathrm{EC} \text {,final values are converted into }}$ non-fossil fractions ( $f_{\mathrm{NF}, \mathrm{OC}}$ and $f_{\mathrm{NF}, \mathrm{EC}}$, respectively) (Szidat et al., 2006; Zhang et al., 2012) using a reference value $\left(f_{\mathrm{NF}, \text { ref }}\right)$ representing the modern ${ }^{14} \mathrm{C}$ content during the sampling period compared to 1950 before the bomb testing. EC is only emitted from fossil sources or biomass burning (neglecting any EC emissions from biofuels as their contribution to the total fuel use is low). Hence, $f_{\mathrm{NF} \text {,ref }}$ equals $f_{\mathrm{M}, \mathrm{bb}}$ to correct $f_{\mathrm{M} \text {,EC }}$ whereas it includes additionally $f_{\mathrm{M} \text {,bio }}$ and the fraction of biogenic sources to the total non-fossil sources ( $p_{\text {bio }}$ ) for the calculation of $f_{\mathrm{NF}, \mathrm{OC}} \cdot f_{\mathrm{M} \text {, bio }}$ was taken from long-term ${ }^{14} \mathrm{CO}_{2}$ measurements at the Schauinsland background station (Levin et al., 2010) and $f_{\mathrm{M}, \mathrm{bb}}$ was estimated using a tree growth model as described in Mohn et al. (2008). $p_{\text {bio }}$ was set to $0.2 \pm 0.2$ since no large contributions from biogenic sources are expected in Switzerland during winter-smog episodes. In any case, $p_{\text {bio }}$ has only a very little impact on $f_{\mathrm{NF} \text {, ref }}$ compared to other measurement uncertainties (e.g., an increase of $p_{\text {bio }}$ from 0.2 to 0.4 would change $f_{\mathrm{NF} \text {, ref }}$ for this study only by max. $1.8 \%$ ). The $f_{\mathrm{M}, \mathrm{bio}}, f_{\mathrm{M}, \mathrm{bb}}$ and $f_{\mathrm{NF} \text {,ref }}$ values for the different years, which were consequently used to determine $f_{\mathrm{NF}, \mathrm{OC}}$ and $f_{\mathrm{NF}, \mathrm{EC}}$, are shown in Table S3. The final uncertainties for $f_{\mathrm{NF}, \mathrm{OC}}$ and $f_{\mathrm{NF}, \mathrm{EC}}(\sim 3$ and $\sim 5 \%$, respectively) were derived from an error propagation and include all the individual uncertainties of the $f_{\mathrm{M}}$ values, $f_{\mathrm{M} \text {,bio }}, f_{\mathrm{M} \text {,bb }}$ and $p_{\text {bio. }}$.

\subsection{Analyses of water-soluble major ionic species and levoglucosan}

The concentrations of major water-soluble ionic species (cations: $\mathrm{K}^{+}, \mathrm{Na}^{+}, \mathrm{Mg}^{2+}, \mathrm{Ca}^{2+}$ and $\mathrm{NH}_{4}^{+}$; anions: methanesulfonate (MSA), oxalate $\left(\mathrm{Ox}^{2-}\right), \mathrm{SO}_{4}^{2-}, \mathrm{NO}_{3}^{-}$and $\left.\mathrm{Cl}^{-}\right)$ were analyzed on all filters $(n=320)$ and field blanks $(n=$ $45)$ with an ion chromatographic system (850 Professional, Metrohm, Switzerland) equipped with a Metrosep C4 cation column and a Metrosep A anion column, respectively. Prior to the measurement a water extraction $(15$ and $50 \mathrm{~mL}$ for samples from 2008-2010 and 2011-2012, respectively) with ultrapure water $\left(18.2 \mathrm{M} \Omega \mathrm{cm}^{-1}\right)$ for $30 \mathrm{~min}$ at $40^{\circ} \mathrm{C}$ in an ultrasonic bath of filter punches with a diameter of $11 \mathrm{~mm}$ was carried out. The measurement uncertainty for most of the water-soluble ions was estimated to be $10 \%$. An uncertainty of $30 \%$ was assigned for all cations as well as for $\mathrm{Ox}^{2-}$ and $\mathrm{Cl}^{-}$with concentrations $<5 \mathrm{ppb}$ in solution. A blank correction was carried out subtracting an average value of each ionic species from the concentrations in the samples. In contrast to the blank correction of the OC and TC concentrations as well as $f_{\mathrm{NF}, \mathrm{OC}}$, where an average value of all blanks (different stations and years) was used, the average of all blanks from the different stations from each winter was taken separately. It should be noted here that not all ionic species were detected in all blanks (see Fig. S1 and Table S2). The overall uncertainty of the major water-soluble ionic species was derived from the error propagation of the measurement uncertainty and the blank variability.

Levoglucosan was measured following the procedures described in Piazzalunga et al. (2010) and (2013a). In brief, levoglucosan was measured by a high-performance anionexchange chromatography (HPAEC) with pulsed amperometric detection (PAD) using an ion chromatograph (Dionex ICS1000) equipped with an isocratic pump and a sample injection valve with a $100 \mu \mathrm{L}$ sample loop. Prior to the analysis, a water extraction was carried out by three subsequent extractions of $\sim 2 \mathrm{~cm}^{2}$ filter punches by 20 min sonication using $2 \mathrm{~mL}$ Millipore-MilliQ water $\left(18.2 \mathrm{M} \Omega \mathrm{cm}^{-1}\right)$. Levoglucosan was then separated from other compounds by a Carbopac PA-10 guard column $(50 \mathrm{~mm} \times 4 \mathrm{~mm})$ and a Carbopac PA-10 anion exchange analytical column $(250 \mathrm{~mm} \times 4 \mathrm{~mm})$ using $18 \mathrm{mM} \mathrm{NaOH}$ as an eluent. The analytical system comprised an amperometric detector (Dionex ED50) equipped with an electrochemical cell. The detector cell had a disposable gold electrode and a $\mathrm{pH}$ electrode as reference (both from Dionex) and was operated in the pulsed amperometric detection (PAD) mode. The measurement uncertainty was estimated to be $\sim 5 \%$ using the average repeatability of several standards and the limit of detection in solution is $2 \mathrm{ppb}$. The levoglucosan concentrations were also analyzed for blank filters but were below the detection limit; therefore no blank correction was performed. 


\subsection{Additional data}

Since all sampling sites in this project are part of the Swiss national (NABEL) or cantonal air pollution monitoring networks, additional parameters (e.g., gas phase pollutants, particle mass and meteorology) are routinely measured. $\mathrm{PM}_{10}$ and nitrogen oxides $\left(\mathrm{NO}_{\mathrm{x}}=\mathrm{NO}\right.$ and $\left.\mathrm{NO}_{2}\right)$ data are available from all stations (except $\mathrm{SCH}$ ), whereas ozone $\left(\mathrm{O}_{3}\right)$, sulfur dioxide $\left(\mathrm{SO}_{2}\right)$ and carbon monoxide $(\mathrm{CO})$ measurements are only performed at some stations. Reference instrumentation according to the valid European standards was used. $\mathrm{PM}_{10}$ is measured online with beta attenuation monitors (FH62IR, Thermo ESM Andersen) and by TEOM-FDMS (Thermo Environmental) instruments and an approach presented in Gehrig et al. (2005) to correct/harmonize online and gravimetric $\mathrm{PM}_{10}$ measurements is routinely applied to data from all stations. It should be noted that $\mathrm{NO}_{\mathrm{x}}$ measurements using molybdenum converters suffer from interference of oxidation products of $\mathrm{NO}_{\mathrm{x}}$ which is however not crucial for winter-time conditions (Steinbacher et al., 2007). The meteorological parameters wind-speed, wind-direction, temperature $(T)$, relative humidity $(\mathrm{RH})$, precipitation and global radiation were also only measured at some of the sites. For the remaining sampling locations meteorological data were taken from nearby stations operated by the Swiss weather service (MeteoSwiss, 2014). In all networks (NABEL, Cantons and MeteoSwiss) data sets (except results obtained offline from filter samples, i.e., EC / OC and levoglucosan concentrations as well as ${ }^{14} \mathrm{C}$ data) undergo an automatic and a manual quality check; data should be (1) within a plausible range, (2) show plausible variability, (3) reproduce to a reasonable extent the expected daily, monthly and yearly variations, and (4) whenever possible measurements are compared to nearby or similar stations with the expectation of similar values (Barmpadimos et al., 2011).

\section{Results and discussion}

\subsection{Composition of $\mathrm{PM}_{10}$}

As we were interested in winter-smog episodes, only days with high $\mathrm{PM}_{10}$ concentrations at all stations were analyzed. As shown in Fig. 2a the selected days from almost all locations exhibited on average values $\sim 50 \mu \mathrm{g} \mathrm{m}^{-3}$ (European and Swiss daily limit) or above. While not exactly the same days were chosen for stations north and south of the main chain of the Alps, it is nevertheless evident that the $\mathrm{PM}_{10}$ burden during winter-smog episodes in Switzerland is higher south of the Alps $\left(73 \pm 27 \mu \mathrm{g} \mathrm{m}^{-3}\right.$ in the south compared to $55 \pm 16 \mu \mathrm{g} \mathrm{m}^{-3}$ in the north). These episodes often occur in winter during stable meteorological conditions including periods with high pressure, rather low temperatures and weak winds (typically less than $2 \mathrm{~m} \mathrm{~s}^{-1}$ ). Such conditions often lead to inversions with low mixing layer heights, thereby favoring the accumulation of pollutants and consequently causing high $\mathrm{PM}_{10}$ concentrations. The reason for the higher $\mathrm{PM}_{10}$ values at stations south of the Alps is most likely due to a combination of topography (e.g., several stations are located in alpine valleys), local meteorology (e.g., more persistent inversions with rather low mixing heights compared to the north) and emissions (strong local wood burning influence, see Sects. 3.2.1 and 3.2.2 below).

As only 5 winter-smog-episode days from each of the five winter seasons were selected and to account for possible differences in the concentration levels between the stations (especially locations north vs. south of the Alps), we will mainly focus here on the fractional contributions of the individual compounds to total $\mathrm{PM}_{10}$. The major water-soluble ions, EC and organic matter $(\mathrm{OM})$ measured here explain $82 \pm 11 \%$ of the total $\mathrm{PM}_{10}$ mass. The missing fraction could mostly be attributed to aerosol water content, the water insoluble fraction (e.g., dust particles), and/or to the uncertainties of the different measurement methods and OM: OC ratio used to convert $\mathrm{OC}$ to $\mathrm{OM}$. The major contributors to $\mathrm{PM}_{10}$ during winter-smog episodes in Switzerland were on average the organic matter $(\mathrm{OM}=\mathrm{OC} \times 1.8$, Turpin and Lim, 2001), with $29 \pm 7$ and $46 \pm 17 \%$ followed by the secondary inorganic aerosol (SIA) constituents nitrate $\left(\mathrm{NO}_{3}^{-}, 25 \pm 9\right.$ and $20 \pm 11 \%$ ), sulfate $\left(\mathrm{SO}_{4}^{2-}, 10 \pm 4\right.$ and $\left.6 \pm 3 \%\right)$ and ammonium $\left(\mathrm{NH}_{4}^{+}, 9 \pm 3\right.$ and $\left.7 \pm 4 \%\right)$ for stations north and south of the Alps, respectively (see Fig. 2). Differences observed in the chemical composition of the aerosol between south and north are a first indication that different emission sources may dominate the aerosol burden at these locations. The EC shares of $\mathrm{PM}_{10}$ were on average $4 \pm 2 \%$ in the north and $6 \pm 3 \%$ in the south.

For stations north of the Alps, the range of OM contribution is rather stable (station averages $23-32 \%$ ), whereas south of the Alps, the OM fraction spans a wider range (station averages $35-52 \%$ ), with values statistically significantly higher than in the north ( $t$ test significant at $95 \%$, in general throughout the manuscript we always used a $t$ test with $p=0.05$ to test the statistical significance of differences between stations north and south of the Alps). Furthermore, a clear trend towards larger $\mathrm{OM}$ contributions at more rural stations is evident in the south. The EC shares of $\mathrm{PM}_{10}$ are on average slightly lower in the north compared to the south but show similar variations among the different stations (averages range between 3-5\% in the north and 5-7\% in the south). As already shown above the contributions of the different SIA components to $\mathrm{PM}_{10}$ are larger in the north. In addition, they also show larger station-to-station differences (averages range from 9-30\% for $\mathrm{NO}_{3}^{-}, 5-11 \%$ for $\mathrm{NH}_{4}^{+}$ and $7-12 \%$ for $\mathrm{SO}_{4}^{2-}$ in the north compared to $14-24 \%$ for $\mathrm{NO}_{3}^{-}, 5-8 \%$ for $\mathrm{NH}_{4}^{+}$and $5-6 \%$ for $\mathrm{SO}_{4}^{2-}$ in the south). While almost all constituents of $\mathrm{PM}_{10}\left(\mathrm{OM}, \mathrm{EC}\right.$ and $\left.\mathrm{NO}_{3}^{-}\right)$ exhibit on average larger concentrations in the south (mainly due to the selection of days with higher $\mathrm{PM}_{10}$ concentrations 

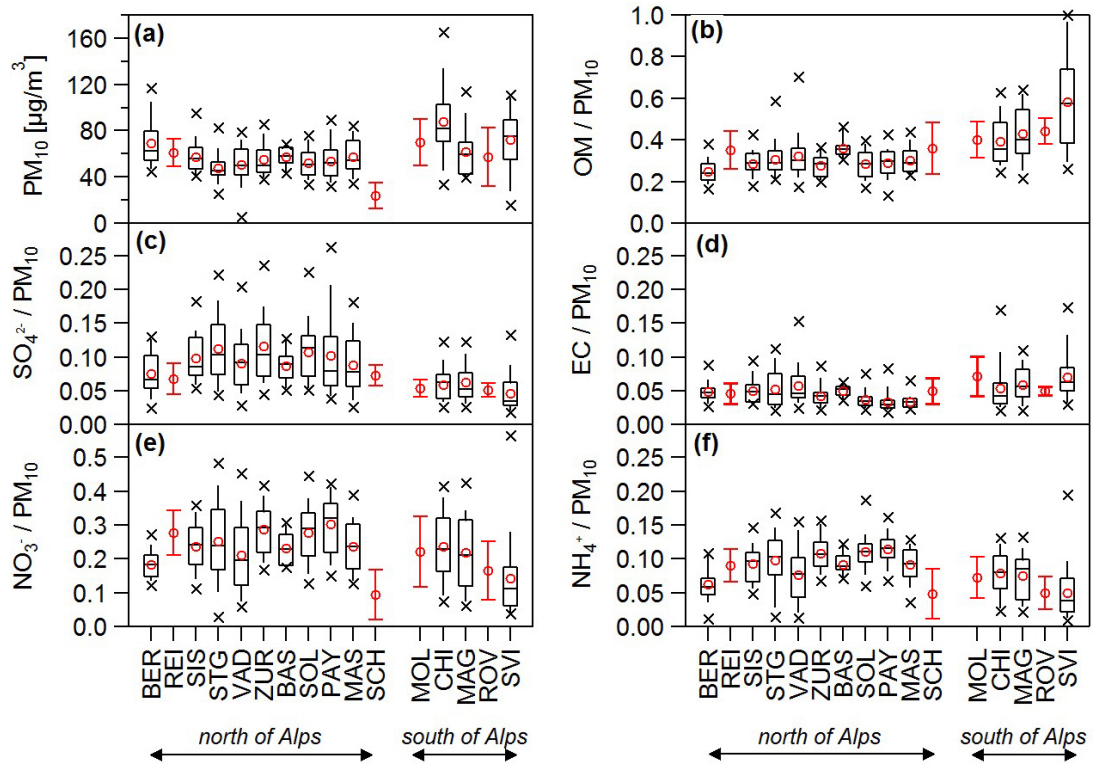

Figure 2. Whisker box plots of the fractional contributions of the major constituents of $\mathrm{PM}_{10}$ (water-soluble ions $\mathrm{NO}_{3}^{-}$, $\mathrm{SO}_{4}^{2-}$ and $\mathrm{NH}_{4}^{+}$as well as $\mathrm{EC}$ and $\mathrm{OM}=\mathrm{OC} \times 1.8)$ from all analyzed winter samples $(n \sim 300)$. The open red circles represent the mean and the black crosses the max. and min. values. The boxes represents the 25 th (lower line), 50th (middle line) and 75th (top line) percentiles. The end of the vertical bars denote the 10th (below the box) and 90th (above the box) percentiles. Stations north and south of the Alps are sorted from the left to the right from the nominal most traffic-influenced station (see Table 1) to the most rural one. Data from the yearly cycle in ZUR are excluded. Only averages \pm standard deviations are displayed for stations from which only filters from one winter were analyzed. The whisker box plots showing the absolute concentrations are presented in Fig. S3.

compared to the ones selected in the north), $\mathrm{NH}_{4}^{+}$shows on average very similar levels in both regions and $\mathrm{SO}_{4}^{2-}$ even higher ones in the north (see Fig. S3). The higher $\mathrm{SO}_{4}^{2-}$ fractions and levels observed north of the Alps indicate a higher background of this species possibly caused by occasional long-range transport of $\mathrm{SO}_{2}$ emissions from Eastern Europe. Another interesting feature is evident for the stations south of the Alps. The relative contributions of $\mathrm{NO}_{3}^{-}$and $\mathrm{NH}_{4}^{+}$exhibit a trend towards lower values at rural stations, as opposed to the OM fraction (see Fig. 2), which may be due to the influence of the stations in the south by air masses advected from the Po Valley, where emissions from fossil fuel combustion (e.g., $\mathrm{NO}_{\mathrm{x}}$ ) are elevated (Piazzalunga et al., 2011b; Larsen et al., 2012) compared to the southern part of Switzerland. More details about the influence of air masses originating from other regions outside Switzerland will be discussed in Zotter et al. (2014).

\section{2 ${ }^{14} \mathrm{C}$-based source apportionment}

\subsubsection{Relative fossil and non-fossil contributions of $\mathrm{OC}$ and EC}

Figure 3 summarizes the individual results of all ${ }^{14} \mathrm{C}$ measurements $(n \sim 300$ for OC and EC) from all stations for the 5 winters (2007/2008-2011/2012), except for REI, MOL, ROV and SCH (one winter) and BAS (two winters), as noted in Table 2. The use of whisker box plots enables the identification of the variability of the results for each station as well as the station-to-station differences. Several filters from BAS showed clearly elevated $f_{\mathrm{NF}, \mathrm{OC}}$ values (larger than one and up to five) indicating that BAS is influenced by sources emitting anthropogenic ${ }^{14} \mathrm{C}$ (e.g., from nuclear power plants, pharmaceutical industry and biochemical laboratories working with labeled ${ }^{14} \mathrm{C}$, incinerators for medical waste). BAS is the base for two of the world's largest pharmaceutical enterprises, Roche and Novartis, and in addition an incinerator for medical waste is located in the vicinity of the station. Furthermore, ${ }^{14} \mathrm{C}$ measurements on leaf samples across the city of Basel also showed partially highly elevated results (BAG, 2008), indicating ${ }^{14} \mathrm{C}$-enriched $\mathrm{CO}_{2}$. Therefore, $f_{\mathrm{NF}, \mathrm{OC}}$ values from BAS were not considered for the further analysis. This artifact is however restricted to OC; the $f_{\mathrm{NF}, \mathrm{EC}}$ results did not show such an influence (see Fig. 3b) and are included and discussed throughout this study. The data from the yearly cycle in ZUR is also excluded here but will be investigated in part II (Zotter et al., 2014).

The range of all $f_{\mathrm{NF}, \mathrm{OC}}$ values (except BAS) as displayed in Fig. 3a is $0.59-0.95$ and $0.62-1.02$ for stations north and south of the Alps, respectively. A few samples $(n=4)$ with $f_{\mathrm{NF}, \mathrm{OC}}$ values slightly above one were found in SVI and are within the uncertainty $(\sim 3 \%)$ of $f_{\mathrm{NF}, \mathrm{OC}}$. They can be explained on the one hand with very high local woodburning contributions and on the other hand with the un- 

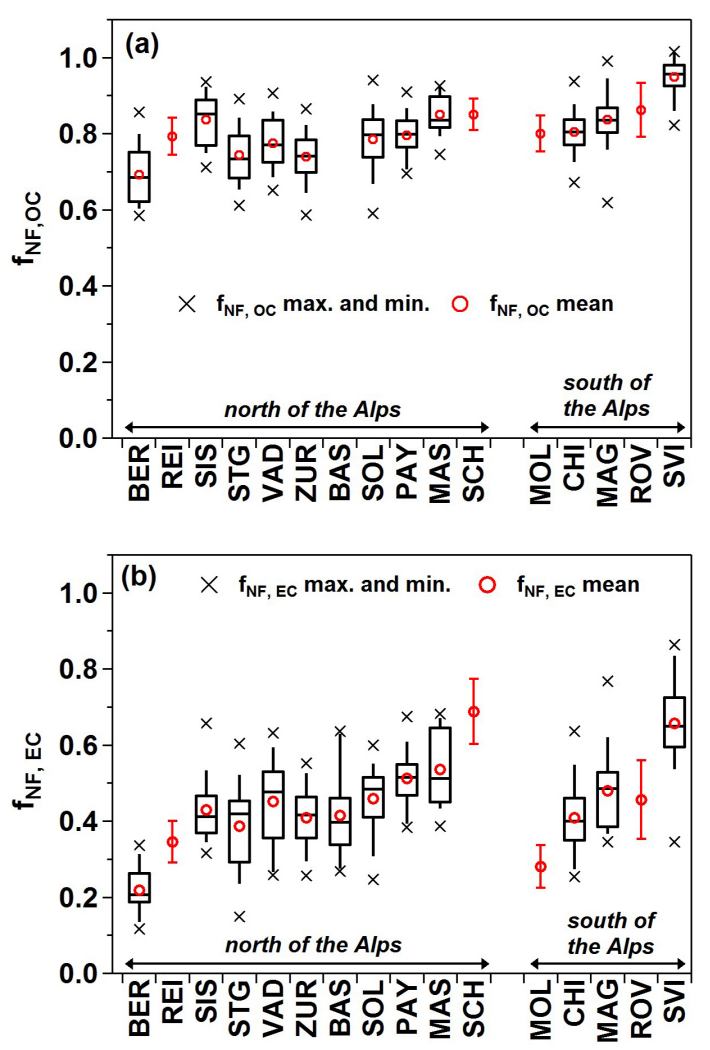

Figure 3. Whisker box plots of the fractional non-fossil contributions of OC (a) and EC (b) summarizing all winter filter samples measured for ${ }^{14} \mathrm{C}$ ( $n \sim 300$ for OC and EC). Stations north and south of the Alps are sorted from the left to the right from the nominal most traffic-influenced station (see Table 1) to the most rural one. Only averages \pm standard deviations are displayed for stations from which only filters from one winter were analyzed. $f_{\mathrm{NF}, \mathrm{OC}}$ values for BAS are not included, since several values above one were found (see Sect. 3.2). Data from the yearly cycle in ZUR are excluded as well.

certainties in the reference value $f_{\mathrm{NF}, \text { ref }}$ used for the correction of the still elevated ${ }^{14} \mathrm{C}$ concentrations due to the above-ground thermo-nuclear bomb tests (see Sect. 2.3.2). The average $f_{\mathrm{NF}, \mathrm{OC}}$ values for stations north and south of the alps are $0.78 \pm 0.08$ (median $=0.78$ ) and $0.82 \pm 0.07$ (median $=0.83$ ), respectively, showing that on average locations south of the Alps are more impacted by non-fossil sources. As discussed above, non-fossil OC may include, POC and SOC from wood burning and cooking emissions, as well as primary biological particles and biogenic SOC. Cooking was estimated to contribute on average only $7.5 \%$ to organic aerosol (OA) during winter in ZUR which is the largest city of Switzerland (Canonaco et al., 2013), and is therefore expected to contribute less at the other stations. Furthermore, large inputs from biological and biogenic sources are also not expected under Swiss winter conditions, characterized by low biological activity. Therefore, the high $f_{\mathrm{NF}, \mathrm{OC}}$ values indicate that wood burning POC and SOC are most proba- bly the main source of OC during winter-smog episodes in Switzerland. The highest $f_{\mathrm{NF}, \mathrm{OC}}$ values north and south of the Alps were found at the rural stations SCH $(0.85 \pm 0.04)$ and SVI $(0.95 \pm 0.05)$, which are located in narrow Alpine valleys. The lowest non-fossil contributions to $\mathrm{OC}$ were observed in BER, STG, VAD and ZUR north of the Alps as well as in MOL and CHI south of the Alps, but were on average never below $70 \%$ showing that sources of fossil carbon only account for a small fraction of OC during winter-smog episodes in Switzerland, even at urban and traffic-influenced stations. Furthermore, the variability of all $f_{\mathrm{NF}, \mathrm{OC}}$ values for the individual stations and the station to station differences (with the exception of SVI and BER which present the highest and lowest values, respectively) are low as displayed by the small interquartile ranges $(\mathrm{IQR}=3 \mathrm{rd}-1$ st quartile; $0.10 \pm 0.02$ in the north and $0.08 \pm 0.02$ south of the Alps) and the small range of the station averages $(0.75-0.85$ and $0.80-0.86$ for stations north and south of the Alps, respectively). This suggests that the relative source contributions to OC are very consistent within Switzerland during wintersmog episodes.

Similar high non-fossil contributions to $\mathrm{OC}$ were also found in previous studies in Switzerland. The $f_{\mathrm{NF}, \mathrm{OC}}$ values for ZUR, ROV, MOL, REI and Sedel as well as MAS, Saxon, Sion and Brigerbad ranged on average from $61-76 \%$ with values above $90 \%$ in ROV (Szidat et al., 2006, 2007; Sandradewi et al., 2008a, b; Perron et al., 2010). Results previously reported for other regions in Europe show lower biomass burning contributions to OC: e.g., biomass burning $\mathrm{OC}\left(\mathrm{OC}_{\mathrm{BB}}\right)$ to the total $\mathrm{OC}$ fraction of $35-54 \%$ at three Austrian cities (Vienna, Graz and Salzburg, Caseiro et al., 2009), $28-65 \%$ at three locations in the Po Valley (Milan, Sondrio and Ispra, Gilardoni et al., 2011; Piazzalunga et al., 2011b) and $60 \%$ in Grenoble (Favez et al., 2010).

The non-fossil fraction of EC relates more unambiguously to wood burning. For most stations the wood burning contribution was found to be $<50 \%$ and thus the contribution from fossil fuel combustion, mostly due to traffic, was $>50 \%$ (see Fig. 3b). However, since the average $f_{\mathrm{NF} \text {,EC }}$ values, except for BER, REI and MOL, never decrease below 0.4, it is evident that wood burning emissions exceptionally account for a large fraction of EC during winter-smog episodes in Switzerland. The individual $f_{\mathrm{NF}, \mathrm{EC}}$ values range from $0.12-0.79$ (on average $0.42 \pm 0.13$ ) and $0.25-0.87$ (on average $0.49 \pm 0.15$ ) for all stations north and south of the Alps, respectively, showing that for EC the contributions from wood burning are higher for locations south of the Alps. The lowest $f_{\mathrm{NF}, \mathrm{EC}}$ values were found at the stations BER $(0.22 \pm 0.06)$, MOL $(0.28 \pm 0.06)$ and REI $(0.35 \pm 0.05)$, which are directly exposed to traffic emissions from nearby roads with a high traffic flow. Extremely high non-fossil contributions to EC up to 87 and $79 \%$ were observed in SVI $(66 \pm 11 \%)$ and SCH $(69 \pm 9 \%)$. Both stations are located in narrow Alpine valleys characterized by frequent winter-time inversions and are strongly influenced by local emissions from wood combus- 
tion, which is the main source for residential heating in such areas in Switzerland.

Elevated non-fossil contributions to EC have already been observed during previous campaigns in Switzerland (71 \pm 18 and $84 \pm 13 \%$ on average in ROV and individual results between 60 and $70 \%$ in MAS, PAY, Sedel, Brigerbad, Saxon and Sion, see Zhang et al. (2012) and references therein). Similar $f_{\mathrm{NF}, \mathrm{EC}}$ results were previously also reported for ZUR (0.24-0.34), BER (0.14), BAS (0.30), MAG (0.30-0.56), MOL (0.24), PAY (0.33-0.43) and REI (0.37) (see Zhang et al. (2012) and Herich et al. (2014), and references therein). $f_{\mathrm{NF}, \mathrm{EC}}$ for stations on the Po-valley (0.16 in Milan, 0.29 in Sondrio and 0.49 in Ispra, Gilardoni et al., 2011; Piazzalunga et al., 2011b) and Grenoble (0.17, Favez et al., 2010) are comparable as well, whereas for two urban stations in Sweden (Gothenburg and Stockholm) a wide range for $f_{\mathrm{NF}, \mathrm{EC}}$ was found (0.12-0.88, Zencak et al., 2007; Szidat et al., 2009; Andersson et al., 2011).

The most prominent feature in Fig. 3 is the clear non-fossil increase south of the Alps from MOL to SVI for OC and EC. With the exception of MOL, which is directly located next to a highway, these stations are not only ordered from the most urban and traffic influenced to the most rural, but also geographically from south to north. $\mathrm{CHI}$ is located in a more open terrain at the Swiss/Italian border, whereas further north, towards the main Alpine chain, narrower alpine valleys dominate and the region is consequently more rural and wood burning for wintertime residential heating becomes more important. The observation that the non-fossil contributions for both, OC and EC, are on average higher at locations south of the Alps can thus be mainly attributed to the fact that there are more rural stations in the south whereas urban and suburban stations dominate north of the Alps (see Fig. 1).

\subsubsection{Total fossil and non-fossil contributions}

Next we will discuss the fossil and non-fossil concentrations of $\mathrm{OC}$ and EC and their contributions to TC. The fraction of TC in $\mathrm{PM}_{10}$ is on average 19-25\% for stations north of the Alps and is slightly higher for locations in the south (27$30 \%$ ). Fig. 4 shows the average $\mathrm{EC}_{\mathrm{F}}, \mathrm{EC}_{\mathrm{NF}}, \mathrm{OC}_{\mathrm{NF}}$ and $\mathrm{OC}_{\mathrm{F}}$ concentrations as well as their relative contributions to $\mathrm{TC}$ for all analyzed winter samples for each station. It is evident that sources of non-fossil carbon dominate TC at locations north and south of the Alps with contributions around $70 \pm 18$ and $79 \pm 10 \%$ (sum of $\mathrm{EC}_{\mathrm{NF}}$ and $\mathrm{OC}_{\mathrm{NF}}$ ), respectively. Compared to other winter measurements across Europe this is rather at the higher end of the reported range and higher than reported for urban sites around the world but similar to values found for suburban and rural locations in the US and India (Hodzic et al., 2010; Heal, 2014).

$\mathrm{OC}_{\mathrm{NF}}$ is the largest fraction of $\mathrm{TC}$, accounting on average for $61 \pm 8$ and $69 \pm 9 \%$ for stations north and south of the Alps, respectively, whereas $\mathrm{EC}_{\mathrm{NF}}$ contributes on average $\sim 9 \%$ to TC in both regions of Switzerland. The fossil
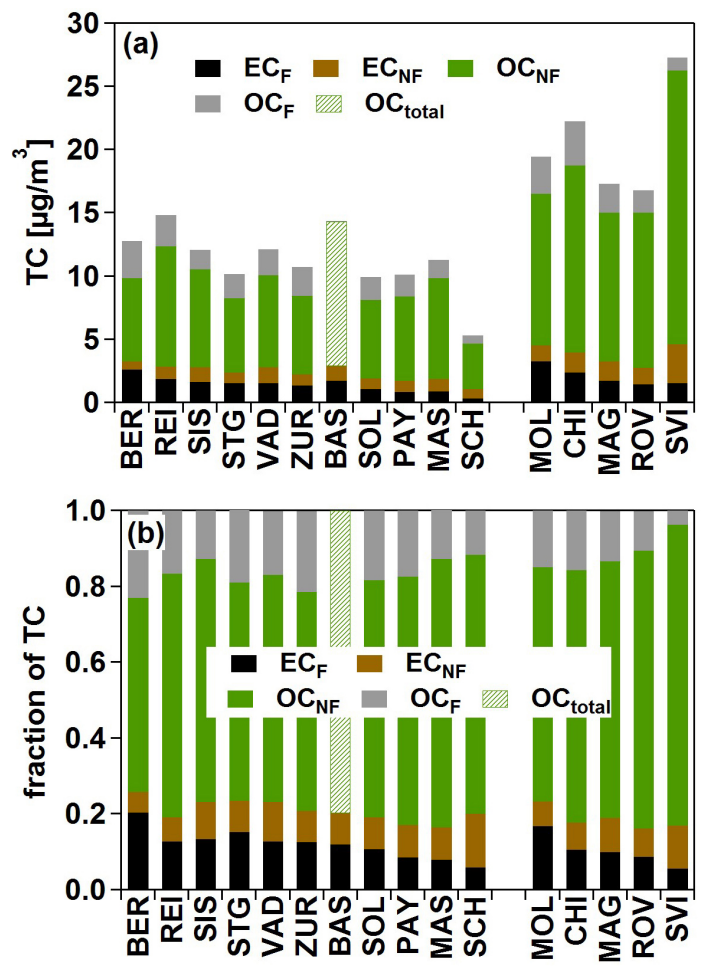

Figure 4. Averages over all analyzed winter samples $(n \sim 300)$ for each station of $\mathrm{EC}_{\mathrm{F}}, \mathrm{EC}_{\mathrm{NF}}, \mathrm{OC}_{\mathrm{NF}}$ and $\mathrm{OC}_{\mathrm{F}}(\mathbf{a})$ as well as their relative contributions to TC (b). Total OC is displayed for BAS since $f_{\mathrm{NF}, \mathrm{OC}}$ values for this station are not included in the analysis due to several values above one (see Sect. 3.2.1). Data from the yearly cycle in ZUR are excluded as well.

shares in the north of OC $(18 \pm 6 \%)$ and EC $(13 \pm 6 \%)$ are higher compared to those in the south $\left(\mathrm{OC}_{\mathrm{F}} / \mathrm{TC}=12 \pm 6 \%\right.$ and $\mathrm{EC}_{\mathrm{F}} / \mathrm{TC} 10 \pm 5 \%$ ). The lowest and highest fossil contributions to TC (sum of $\mathrm{EC}_{\mathrm{F}}$ and $\mathrm{OC}_{\mathrm{F}}$ ) were found in SVI $(10 \pm 6 \%)$ and BER $(43 \pm 7 \%)$, respectively. For the stations south of the Alps, a clear decreasing trend in the relative contribution of fossil OC and EC from more traffic to more rurally influenced stations is found (see Fig. 4 and Fig. S4). North of the Alps, such a trend is only evident for $\mathrm{EC}_{\mathrm{F}}$. Relative and absolute non-fossil OC and EC contributions in the north (except BER and SCH which present the highest and lowest values) only show low station-to-station differences (station averages range from $58-71 \%$ and $1.5-2.5 \mu \mathrm{g} \mathrm{C} \mathrm{m}^{-3}$ for $\mathrm{OC}_{\mathrm{NF}}$ as well as $8-11 \%$ and $0.9-1.9 \mu \mathrm{g} \mathrm{C} \mathrm{m}^{-3}$ for $\mathrm{EC}_{\mathrm{NF}}$, see Fig. 4 and Fig. S4). In addition, also the variability of the relative and absolute $\mathrm{OC}_{\mathrm{NF}}$ and $\mathrm{EC}_{\mathrm{NF}}$ contributions at the individual stations north of the Alps is rather small as evidenced by low IQRs $\left(2.8 \pm 0.9 \mu \mathrm{g} \mathrm{C} \mathrm{m}^{-3}\right.$ and $7 \pm 2 \%$ for $\mathrm{OC}_{\mathrm{NF}}$ as well as $0.4 \pm 0.1 \mu \mathrm{g} \mathrm{C} \mathrm{m}^{-3}$ and $3 \pm 1 \%$ for $\mathrm{EC}_{\mathrm{NF}}$ ). Together with the low station-to-station differences, this suggests that non-fossil sources very consistently influence stations on the Swiss Plateau. Furthermore, as discussed above, $\mathrm{OC}_{\mathrm{NF}}$ can be influenced by SOC formation which can be 
highly variable. However, the low $\mathrm{OC}_{\mathrm{NF}}$ station-to-station and day-to-day variability points to a similar degree of atmospheric processing and SOC formation for the chosen days in this region of Switzerland. Last, the low absolute and relative $\mathrm{EC}_{\mathrm{NF}}$ and $\mathrm{OC}_{\mathrm{NF}} \mathrm{IQRs}$ at the individual stations and station-to-station differences also indicate that locations on the Swiss Plateau are rather influenced by regional (still mainly within Switzerland) air pollution. This is confirmed by high correlations $(r=0.7 \pm 0.2,0.5 \pm 0.3,0.9 \pm 0.1$ and $0.7 \pm 0.1)$ between the concentrations of $\mathrm{EC}_{\mathrm{F}}, \mathrm{EC}_{\mathrm{NF}}, \mathrm{OC}_{\mathrm{F}}$ and $\mathrm{OC}_{\mathrm{NF}}$ for all measured values from each station located on the Swiss Plateau (see Table 1) against ZUR which was chosen as a reference for this region. Furthermore, this is in agreement with Gehrig and Buchmann, 2003) who previously found that (1) under high pressure conditions inversions can extend over the entire Swiss Plateau and typically last several days possibly causing smog formation and (2) that PM concentrations were strongly influenced by meteorology (dilution with clean air or precipitation) rather than by variation of source activities. In contrast, correlating the fossil and non-fossil concentrations of OC and EC from stations south of the Alps against the ones from MAG shows lower values $(r=0.3 \pm 0.2,0.6 \pm 0.3,0.4 \pm 0.3$ and $0.3 \pm 0.3$ for $\mathrm{OC}_{\mathrm{NF}}, \mathrm{EC}_{\mathrm{NF}}, \mathrm{EC}_{\mathrm{F}}$ and $\mathrm{OC}_{\mathrm{F}}$, respectively) indicating that local sources are more important for stations south of the Alps.

\subsection{Sources and behavior of fossil and non-fossil organic carbon}

\subsubsection{Fossil fraction}

Figure 5 presents the comparison between $\mathrm{EC}_{\mathrm{F}}, \mathrm{OC}_{\mathrm{F}}$ and $\mathrm{NO}_{\mathrm{x}}$, which are expected to be associated with traffic emissions, in Switzerland. $\mathrm{EC}_{\mathrm{F}}$, which is emitted as primary aerosol from vehicles, exhibits a high correlation with $\mathrm{NO}_{\mathrm{x}}$ for the stations north $(r=0.79)$ and south $(r=0.75)$ of the Alps, with similar slopes and axis intercepts for both regions $\left(0.021\right.$ and $0.015 \mu \mathrm{g} \mathrm{Cm}^{-3} \mathrm{ppb}^{-1}$ and 0.35 and $0.89 \mu \mathrm{g} \mathrm{C} \mathrm{m}^{-3}$ for north and south of the Alps, respectively (see Fig. 5c), indicating a rather similar fleet composition in the two areas. Similar slopes $(0.05,0.03$ and $0.02 \mu \mathrm{g} \mathrm{C} \mathrm{m}^{-3} \mathrm{ppb}^{-1}$ ) have been reported previously for three locations in Switzerland (MAG, ZUR and PAY, Herich et al., 2011), Grenoble (Favez et al., 2010) and London (Liu et al., 2014). In contrast, no correlation is found between $\mathrm{OC}_{\mathrm{F}}$ and the primary vehicular markers, $\mathrm{EC}_{\mathrm{F}}$ and $\mathrm{NO}_{\mathrm{x}}$ $(r<0.5$, see Fig. $5 b)$ for stations both north and south of the Alps. Further, the amounts of fossil organic carbon measured are significantly higher than amounts expected for traffic emissions; i.e., observed average $\mathrm{OC}_{\mathrm{F}} / \mathrm{EC}_{\mathrm{F}}=1.54 \pm 0.83$ vs. traffic OC / EC $=0.25-0.80$ (El Haddad et al., 2013 and references therein). Taken together these observations indicate that a considerable amount of $\mathrm{OC}_{\mathrm{F}}$ is associated with emissions or atmospheric pathways that yield organic aerosol with little or no $\mathrm{EC}_{\mathrm{F}}$ and $\mathrm{NO}_{\mathrm{x}}$. These processes may in- clude primary emissions from non-mobile fossil fuel combustion sources, e.g., heavy fuel combustion (e.g., crude oil, not widely used in Switzerland), or secondary organic carbon formed from fossil VOCs emitted from traffic.

\subsubsection{Non-fossil fraction}

As mentioned above a significant fraction of non-fossil carbon during winter-smog episodes originates from wood burning. The use of a single or a set of source specific compound markers from wood burning emissions is often applied to estimate the contribution of this source to ambient aerosol (Herich et al., 2014 and references therein). The most widely used tracer compound for biomass-burning emissions is levoglucosan (Simoneit et al., 1999; Puxbaum et al., 2007), a product of cellulose combustion. Another wood burning tracer is water-soluble potassium $\left(\mathrm{K}^{+}\right)$, which is an inorganic compound mainly present in ash. The wide variability of levoglucosan emission ratios results in significant uncertainties in estimating wood burning contributions. For example, ratios of OC and EC to levoglucosan for alpine regions were reported in Schmidl et al. (2008) to range from 3.7 to 12.5 and from 0.7 to 4.7 , respectively, dependent on the combustion conditions and fuel type used (Engling et al., 2006; Lee et al., 2010). Here, we examine the relationship between different measured wood burning markers and the measured $\mathrm{OC}_{\mathrm{NF}}$, to investigate the main emission sources and chemical characteristics of this fraction.

The comparison of $\mathrm{EC}_{\mathrm{NF}}$ and $\mathrm{OC}_{\mathrm{NF}}$ with levoglucosan (see Fig. 6) shows a high correlation for both species with the latter. The small intercept ( 1.3 and $2.3 \mu \mathrm{g} \mathrm{m}^{-3}$ for stations north and south of the Alps, respectively) and the high correlation $(r>0.87)$ between $\mathrm{OC}_{\mathrm{NF}}$ and levoglucosan suggests that the majority of $\mathrm{OC}_{\mathrm{NF}}$ originates from wood combustion; i.e., cooking and, biogenic emissions seem to be minor contributors (see Sect. 3.2.1 above). Furthermore, this indicates that $\mathrm{OC}_{\mathrm{NF}}$ is to a large extent emitted as primary aerosol, however, with the data presented in this study it is not possible to quantify a primary vs. secondary fraction of woodburning OC. $\mathrm{OC}_{\mathrm{NF}}$ also exhibits a high correlation with $\mathrm{K}^{+}$ as well ( $\mathrm{r}=0.62$ in the north and $r=0.87$ in the south, see Fig. 8a). However, $\mathrm{K}^{+}$is also found in soil dust and sea salt or can be formed in incinerators and during meat cooking (Schauer et al., 1999, 2001), and therefore cannot be used as unambiguous tracer for wood burning, although none of these sources are expected to have a large influence in Switzerland during winter. Another indication for $\mathrm{OC}_{\mathrm{NF}}$ originating to a large extent from wood combustion is its high correlation ( $r=0.77$, see Fig. 7) with $\mathrm{EC}_{\mathrm{NF}}$, which can be almost exclusively attributed to this source.

A high correlation is also found between levoglucosan and $\mathrm{K}^{+}(r>0.6)$. However, clearly different slopes (0.6 and 5.4) are observed for stations north and south of the Alps, respectively. Furthermore, also the comparison of $\mathrm{OC}_{\mathrm{NF}}$ and $\mathrm{EC}_{\mathrm{NF}}$ with levoglucosan as well as $\mathrm{OC}_{\mathrm{NF}}$ with $\mathrm{K}^{+}$shows signifi- 

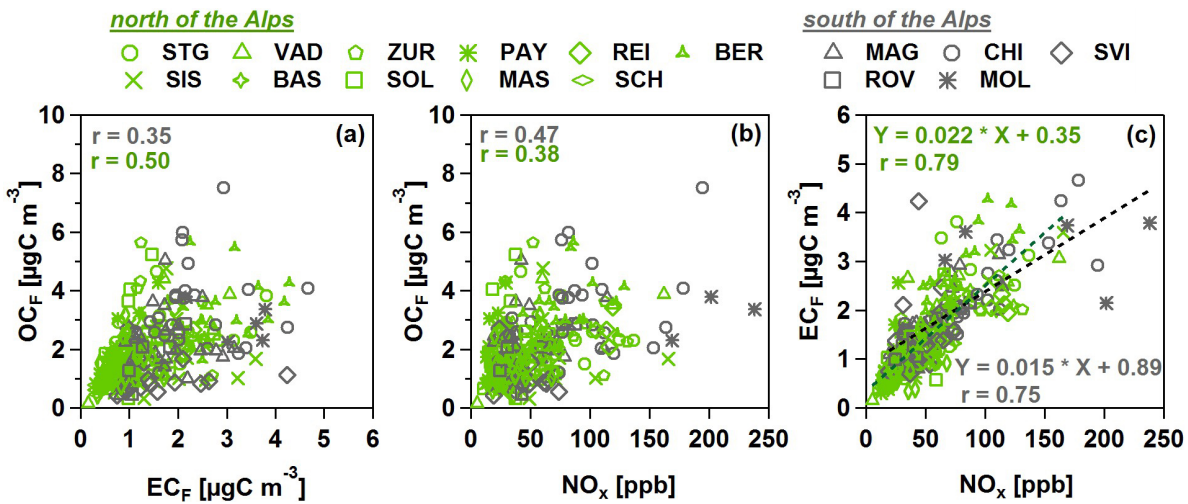

Figure 5. Comparison for stations north and south of the Alps for (a) $\mathrm{EC}_{\mathrm{F}}$ and $\mathrm{OC}_{\mathrm{F}}$, (b) $\mathrm{NO}_{\mathrm{x}}$ and $\mathrm{OC}_{\mathrm{F}}$ as well as $(\mathbf{c}) \mathrm{NO}_{\mathrm{x}}$ and $\mathrm{EC}_{\mathrm{F}}$. OC $\mathrm{F}$ values from BAS and all data from the yearly cycle in ZUR are excluded (see Sect. 3.2.1 and Sect. 1). An orthogonal distance regression was used to fit the data.
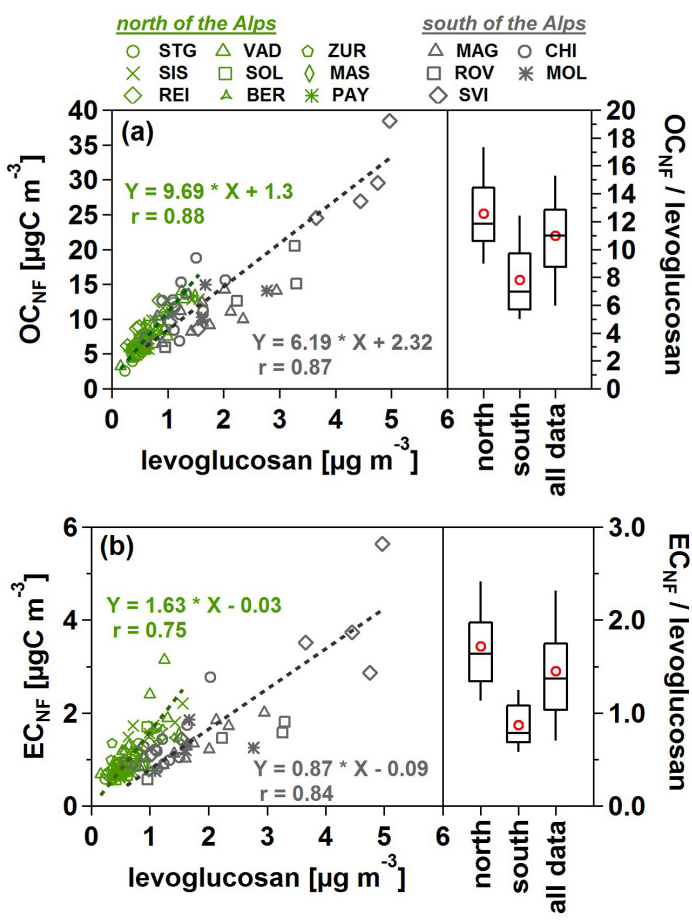

Figure 6. Scatter plot of $\mathrm{OC}_{\mathrm{NF}}$ (a) and $\mathrm{EC}_{\mathrm{NF}}(\mathbf{b})$ vs. levoglucosan combined with whisker box plots of their ratios for all measured winter samples (red circles denote the mean). $\mathrm{OC}_{\mathrm{NF}}$ values from BAS and all data from the yearly cycle in ZUR are excluded (see Sect. 3.2.1 and Sect. 1). Levoglucosan data is only available for the first two winter seasons (see Table 2). An orthogonal distance regression was used to fit the data.

cantly different ratios for stations located in the north and the south. These discrepancies between the two Swiss regions could originate from different wood types used (e.g., soft and hard wood), burning conditions, and atmospheric processing. Different ratios of $\mathrm{OC}_{\mathrm{NF}}$ and $\mathrm{EC}_{\mathrm{NF}}$ to levoglucosan indicate differences in SOC formation and/or photochemi- cal degradation of the latter which was recently reported by Kessler et al. (2010) and Hennigan et al. (2011). However, under winter-smog conditions in Switzerland (low temperatures and photochemical activity) rapid levoglucosan degradation is not expected and no large systematic differences in the photochemical activity and SOC formation between locations south and north of the Alps were found as evidenced by very similar $\mathrm{OC}_{\mathrm{NF}}$ to $\mathrm{EC}_{\mathrm{NF}}$ ratios $(7.7 \pm 2.1$ and $8.6 \pm 2.9$, see Table 3 and Fig. 7) for these two regions in Switzerland. However, with our data we cannot completely rule out different wood burning OC / EC emission ratios in both regions of Switzerland as higher primary wood burning OC emissions in the south could be compensated by a larger non-fossil SOC fraction in the north. Higher ratios of $\mathrm{OC}_{\mathrm{NF}}$ and levoglucosan to $\mathrm{K}^{+}$in the south show that wood burning emissions contain a higher fraction of OC compared to the north. Data from the Swiss forest inventory (Swiss Federal Statistical Office, 2014) show that the fraction of soft $(25 \%)$ and hard woods $(75 \%)$ in the energy wood production is very similar between the Swiss Plateau and the regions south of the Alps (max. $16 \%$ difference for the years 2008-2012) suggesting that households in both regions have similar access to soft and hard woods. Therefore, the different ratios between $\mathrm{OC}_{\mathrm{NF}}$ and $\mathrm{K}^{+}$as well as levoglucosan and $\mathrm{K}^{+}$are most likely due to different burning conditions. Previous studies demonstrated that particulate emissions from biomass combustion with high temperatures (e.g., in large combustion units, modern stoves and boilers) consist predominantly of inorganic material (K-salts) and contain little OC (Valmari et al., 1998; Johansson et al., 2003; Khalil and Rasmussen, 2003; Heringa et al., 2011; Schmidl et al., 2011). Consequently, dissimilar levoglucosan to $\mathrm{K}^{+}$ratios measured at different locations have already been used as indication for different burning conditions in recent studies (Sandradewi et al., 2008b; Caseiro et al., 2009; Piazzalunga et al., 2013b). The lower levoglucosan to $\mathrm{K}^{+}$ratios found in this study for locations north of the Alps therefore suggest 


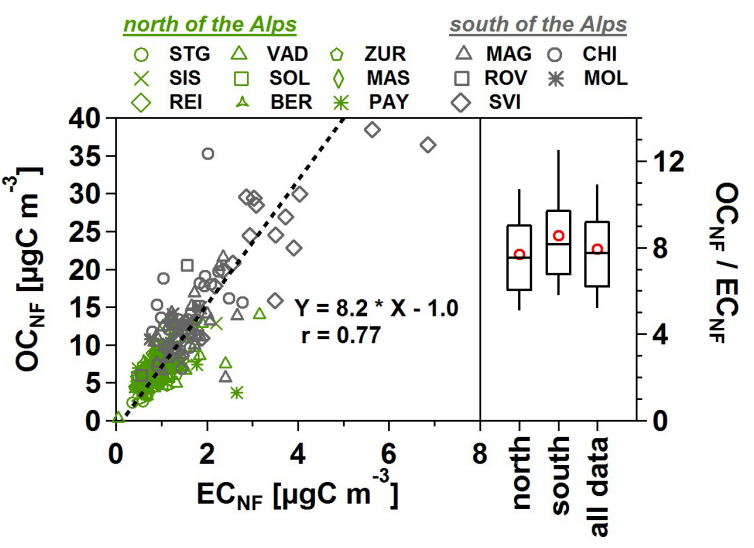

Figure 7. Comparison of $\mathrm{OC}_{\mathrm{NF}}$ and $\mathrm{EC}_{\mathrm{NF}}$ combined with whisker box plots of their ratios for all measured winter samples (red circles denote the mean). $\mathrm{OC}_{\mathrm{NF}}$ values from BAS and all data from the yearly cycle in ZUR are excluded (see Sect. 3.2.1 and Sect. 1). An orthogonal distance regression was used to fit the data.

a larger fraction of more efficient wood burners (e.g., pellet and wood chip burners) in this region compared to the south where wood stoves seem to be operated at rather poor combustion conditions with high carbonaceous and thus lower relative $\mathrm{K}^{+}$emissions.

The discussions above clearly showed the differences in wood burning marker ratios at locations north and south of the Alps. However, a closer inspection of the results of Table 3 reveals that most wood burning marker ratios at the stations PAY and MAS (both north of the Alps) are rather similar to the average over all locations south of the Alps and the urban station CHI exhibits values more similar to the average in the north than to the other southern locations. Since in the north mainly urban and suburban stations and south of the Alps mostly rural and/or background sites were chosen (see Table 1 and Fig. 1), this suggests that the differences in the wood burning marker ratios between these two Swiss regions are most likely associated with the different station characteristics (e.g., rural and/or background with high wood burning influence vs. urban, suburban and more traffic influenced stations) rather than due to their geographical location within Switzerland.

\subsubsection{Comparison of wood burning marker ratios with other studies}

Herich et al. (2014) presented an overview about previous studies carried out during winter in Switzerland and other alpine regions in Europe. Several source apportionment methods (including ${ }^{14} \mathrm{C}$ analysis, aethalometer model, positive matrix factorization, chemical mass balance, macrotracer approach - see Gianini et al. (2013) and Herich et al. (2014) for a discussion about possible differences in the biomass burning marker ratios due to different approaches) were used in these studies to estimate the wood burning frac-
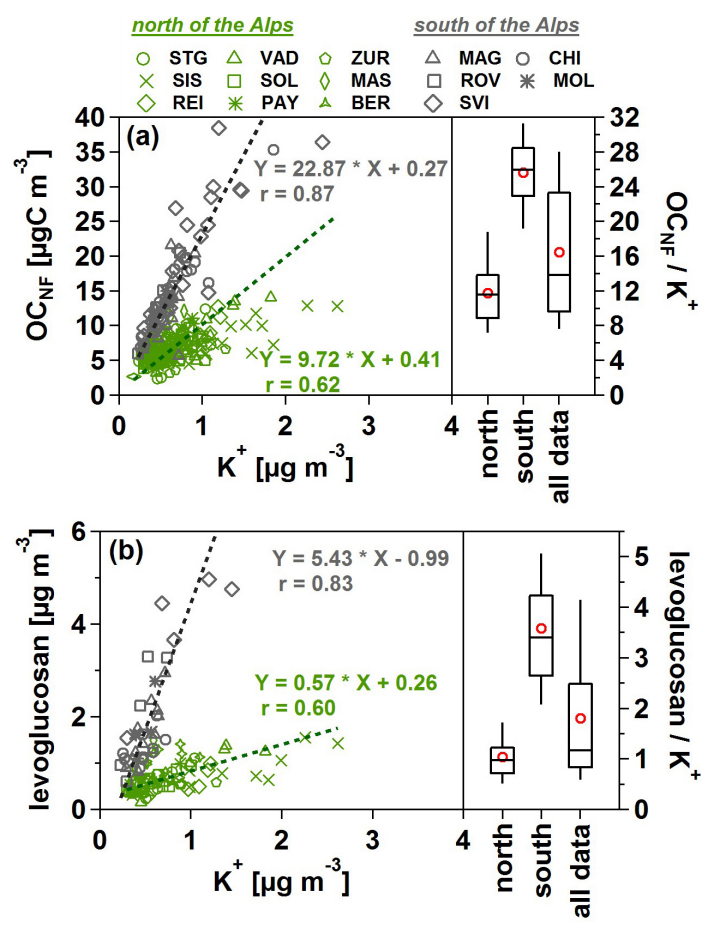

Figure 8. $\mathrm{OC}_{\mathrm{NF}}$ (a) and levoglucosan (b) as a function of the $\mathrm{K}^{+}$ concentrations combined with whisker box plots of their ratios for all measured winter samples (red circles denote the mean). $\mathrm{OC}_{\mathrm{NF}}$ values from BAS and all data from the yearly cycle in ZUR are excluded (see Sect. 3.2.1 and Sect. 1). Levoglucosan data is only available for the first two winter seasons (see Table 2). An orthogonal distance regression was used to fit the data.

tion of OC and EC. In the following we will compare our biomass burning marker ratios with the ones summarized by Herich et al. (2014). It should be noted that the results presented in the latter study were mainly obtained from short campaigns in just a single winter season and at a limited number of stations, whereas here we performed measurements on winter filters from 5 years and 16 stations.

The average $\mathrm{EC}_{\mathrm{NF}}$ to levoglucosan ratio for several stations north of the Alps (BER, PAY, STG, ZUR, REI, BAS, Ebnat-Kappel) from earlier winter measurements in Switzerland is consistent with the results obtained here, but for some southern stations (MAG, MOL, ROV) it is slightly higher than the average ratio found here (see Table 3 ). $\mathrm{EC}_{\mathrm{NF}}$ / levoglucosan ratios for three Austrian cities (Vienna, Graz and Salzburg, Caseiro et al., 2009) and three locations in the Po Valley (Milan, Sondrio and Ispra, Gilardoni et al., 2011; Piazzalunga et al., 2011b) which can be considered as north and south of the main chain of the Alps, respectively, exhibit also similar values as those obtained here. Generally lower biomass burning $\mathrm{OC}\left(\mathrm{OC}_{\mathrm{BB}}\right)$ to levoglucosan and $\mathrm{OC}_{\mathrm{BB}}$ to $\mathrm{EC}_{\mathrm{NF}}$ ratios for the Swiss, Po-valley and Austrian sites located north and south of the Alps were found in Herich et al. (2014) compared to $\mathrm{OC}_{\mathrm{NF}}$ to levoglucosan 
Table 3. Compilation of the ratios between levoglucosan (Levo) and $\mathrm{K}^{+}, \mathrm{EC}_{\mathrm{NF}}$ and levoglucosan, $\mathrm{OC}_{\mathrm{NF}}$ and levoglucosan as well as $\mathrm{OC}_{\mathrm{NF}}$ and $\mathrm{EC}_{\mathrm{NF}}$ for all stations. Numbers indicate the mean values \pm standard deviation. The number of samples is reported in brackets. $\mathrm{OC}_{\mathrm{F}}$ values from BAS and all data from the yearly cycle in ZUR are excluded (see Sect. 3.2.1 and Sect. 1). No levoglucosan was measured in $\mathrm{SCH}$. In addition, ratios previously reported in literature ${ }^{\mathrm{a}}$ for similar conditions are included as well.

\begin{tabular}{lrrrr}
\hline station & $\mathrm{EC}_{\mathrm{NF}} / \mathrm{Levo}$ & $\mathrm{OC}_{\mathrm{NF}}^{\mathrm{b}} / \mathrm{Levo}$ & $\mathrm{OC}_{\mathrm{NF}}^{\mathrm{b}} / \mathrm{EC}_{\mathrm{NF}}$ & Levo $^{+} \mathrm{K}^{+}$ \\
\hline REI & $1.76 \pm 0.49(n=5)$ & $17.3 \pm 4.2(n=5)$ & $9.9 \pm 1.3(n=5)$ & $0.59 \pm 0.16(n=5)$ \\
BER & $1.74 \pm 0.21(n=5)$ & $15.5 \pm 2.2(n=5)$ & $9.4 \pm 1.6(n=25)$ & $0.87 \pm 0.12(n=5)$ \\
BAS & $1.29 \pm 0.28(n=9)$ & - & - & $1.52 \pm 0.47(n=10)$ \\
PAY & $1.26 \pm 0.21(n=5)$ & $10.4 \pm 1.1(n=5)$ & $8.3 \pm 2.5(n=25)$ & $1.37 \pm 0.32(n=5)$ \\
SIS & $1.79 \pm 0.46(n=9)$ & $12.9 \pm 3.7(n=8)$ & $6.7 \pm 1.4(n=21)$ & $0.63 \pm 0.21(n=10)$ \\
SOL & $1.42 \pm 0.33(n=9)$ & $11.8 \pm 2.2(n=10)$ & $7.8 \pm 2.0(n=25)$ & $1.05 \pm 0.25(n=10)$ \\
MAS & $1.15 \pm 0.13(n=5)$ & $10.9 \pm 2.0(n=5)$ & $8.4 \pm 1.5(n=20)$ & $2.05 \pm 0.43(n=5)$ \\
ZUR & $2.12 \pm 0.79(n=9)$ & $13.1 \pm 2.2(n=9)$ & $7.3 \pm 2.0(n=25)$ & $0.80 \pm 0.22(n=10)$ \\
VAD & $2.43 \pm 0.78(n=9)$ & $12.1 \pm 3.5(n=10)$ & $5.9 \pm 1.5(n=25)$ & $0.88 \pm 0.24(n=10)$ \\
STG & $1.77 \pm 0.29(n=14)$ & $11.7 \pm 2.0(n=14)$ & $7.4 \pm 1.9(n=25)$ & $0.97 \pm 0.26(n=13)$ \\
SCH & - & - & $5.1 \pm 1.2(n=3)$ & - \\
MOL & $0.77 \pm 0.24(n=5)$ & $7.3 \pm 2.0(n=5)$ & $9.9 \pm 2.9(n=5)$ & $3.67 \pm 0.83(n=5)$ \\
ROV & $0.76 \pm 0.43(n=5)$ & $7.0 \pm 3.0(n=5)$ & $9.7 \pm 2.1(n=5)$ & $4.39 \pm 1.53(n=5)$ \\
CHI & $1.01 \pm 0.28(n=10)$ & $9.9 \pm 2.8(n=10)$ & $9.8 \pm 3.7(n=25)$ & $2.87 \pm 0.97(n=10)$ \\
MAG & $0.80 \pm 0.17(n=10)$ & $6.9 \pm 2.6(n=10)$ & $7.9 \pm 2.4(n=25)$ & $3.29 \pm 0.73(n=10)$ \\
SVI & $0.93 \pm 0.19(n=6)$ & $6.9 \pm 1.4(n=6)$ & $7.3 \pm 1.9(n=22)$ & $4.49 \pm 1.20(n=6)$ \\
north of Alps & $1.72 \pm 0.59(n=79)$ & $12.6 \pm 3.1(n=71)$ & $7.7 \pm 2.1(n=199)$ & $1.03 \pm 0.46(n=83)$ \\
south of Alps & $0.87 \pm 0.27(n=36)$ & $7.8 \pm 2.7(n=36)$ & $8.6 \pm 2.9(n=82)$ & $3.58 \pm 1.16(n=36)$ \\
Austria ${ }^{c}$ & $1.31 \pm 0.11$ & $7.24 \pm 0.03$ & $5.57 \pm 0.48$ & - \\
Po-valley & $0.89 \pm 0.06$ & $5.62 \pm 0.30$ & $6.54 \pm 0.25$ & - \\
north of Alps & $1.82 \pm 0.44$ & $9.05 \pm 1.77$ & $4.98 \pm 0.39$ & - \\
south of Alps ${ }^{\mathrm{f}}$ & $1.20 \pm 0.37$ & $7.04 \pm 0.90$ & $4.72 \pm 0.04$ & - \\
\hline
\end{tabular}

a data from the publications listed below were summarized and recalculated by Herich et al. (2014). ${ }^{\mathrm{b}}$ Herich et al. (2014) obtained biomass burning $\mathrm{OC}\left(\mathrm{OC}_{\mathrm{BB}}\right)$ ratios which do not include SOA. ${ }^{\mathrm{c}}$ average over measurements in winter from Vienna, Graz and Salzburg (Caseiro et al., 2009). ${ }^{\mathrm{d}}$ average over measurements in winter from Milan, Sondrio and Ispra (Gilardoni et al., 2011; Piazzalunga et al., 2011b). ${ }^{\mathrm{e}}$ average over measurements in winter from BER, PAY, STG, ZUR, REI, BAS, Ebnat-Kappel (Sandradewi et al., 2008b; Herich et al., 2011; Gianini et al., 2012). ${ }^{\mathrm{f}}$ average over measurements in winter from MAG, MOL, ROV (Sandradewi et al., 2008b; Herich et al., 2011; Gianini et al., 2012).

and $\mathrm{OC}_{\mathrm{NF}}$ to $\mathrm{EC}_{\mathrm{NF}}$ ratios presented here (see Table 3). The differences in the ratios most likely originate from (1) uncertainties in the $\mathrm{OC}_{\mathrm{BB}}$ determination (e.g., $\mathrm{OC} /$ levoglucosan emission ratios have to be assumed which can be highly variable) (2) SOC from wood burning is not taken into account in the $\mathrm{OC}_{\mathrm{BB}}$ values as presented in Herich et al. (2014) but is included in $\mathrm{OC}_{\mathrm{NF}}$ as obtained by the ${ }^{14} \mathrm{C}$ measurement and (3) a contribution of other non-fossil sources (e.g., cooking or biogenic aerosol) to $\mathrm{OC}_{\mathrm{NF}}$ as apportioned with the ${ }^{14} \mathrm{C}$ analysis cannot be completely ruled out although they are expected to have no large influence during winter-smog episodes in Switzerland (see discussion in Sect. 3.2.1 above).

The differences in the wood burning marker ratios between locations north and south of the Alps is also evident for the results presented in Herich et al. (2014). $\mathrm{OC}_{\mathrm{BB}}$ and $\mathrm{EC}_{\mathrm{NF}}$ to levoglucosan ratios are higher in the north which was also shown for the same ratios obtained here. In addition, $\mathrm{OC}_{\mathrm{BB}} / \mathrm{EC}_{\mathrm{NF}}$ previously found for stations north and south of the Alps in Switzerland are very similar confirming the findings from above (see Sect. 3.3.2) that there is no significant difference in the non-fossil SOC formation between these two regions.

\section{Conclusions}

In this study we present source apportionment results of winter-smog episodes in Switzerland (days exceeding the Swiss and European daily $\mathrm{PM}_{10}$ limit of $50 \mu \mathrm{g} \mathrm{m}^{-3}$ ) using radiocarbon $\left({ }^{14} \mathrm{C}\right)$ analysis separated for the elemental (EC) and organic (OC) carbon fraction together with levoglucosan, major water-soluble ionic species and gas phase pollutant measurements. Overall, $\sim 300$ filter samples from five winter seasons (2008-2012) from 16 air pollution monitoring stations across Switzerland with different characteristic (e.g., urban, suburban, rural, alpine valley, traffic, background, etc.) were analyzed providing one of the world's largest aerosol ${ }^{14} \mathrm{C}$ data sets.

The most important contributions to $\mathrm{PM}_{10}$ during wintersmog episodes in Switzerland were on average the organic matter OM $(29 \pm 7$ and $46 \pm 17 \%)$, followed by the secondary inorganic constituents nitrate $\left(\mathrm{NO}_{3}^{-}, 25 \pm 9\right.$ and $20 \pm 11 \%)$, sulfate $\left(\mathrm{SO}_{4}^{2-}, 10 \pm 4\right.$ and $\left.6 \pm 3 \%\right)$ and ammonium $\left(\mathrm{NH}_{4}^{+}, 9 \pm 3\right.$ and $\left.7 \pm 4 \%\right)$ for stations north and south of the Alps, respectively. The EC shares of $\mathrm{PM}_{10}$ were on average 3-5\% north of the Alps and 5-7\% south of the Alps. 
$\mathrm{PM}_{10}$ and $\mathrm{OM}$ concentrations during winter-smog episodes in Switzerland were significantly higher for stations south of the Alps, which is most likely due to a combination of topography (e.g., several stations are located in alpine valleys), local meteorology (e.g., more persistent inversions with rather low mixing heights compared to the north) and emissions (strong local wood burning influence).

The fractional non-fossil contribution of organic carbon $\left(f_{\mathrm{NF}, \mathrm{OC}}\right)$ determined with the ${ }^{14} \mathrm{C}$ analysis ranges on average between $0.69-0.85$ and $0.80-0.95$ for stations north and south of the Alps, respectively, showing that traffic contributes on average only up to $30 \%$ to OC. Furthermore, the elevated $f_{\mathrm{NF}, \mathrm{OC}}$ values together with high correlations with other wood burning markers (non-fossil EC, levoglucosan and water soluble potassium) indicate that residential wood burning is the major source of OC during winter smog episodes in Switzerland. The station-to-station differences and the variability at each individual location north of the Alps is small suggesting that on the one hand the relative source contributions, meteorological conditions, as well as the degree of atmospheric processing and secondary OC formation for the chosen days were very similar and on the other hand that different stations, especially those on the Swiss Plateau, are rather influenced by regional air pollution than from local sources. The relative non-fossil contributions of EC ( $\left.f_{\mathrm{NF}, \mathrm{EC}}\right)$, which can be exclusively attributed to wood burning, are on average $0.42 \pm 0.13$ and $0.49 \pm 0.15$ for stations north and south of the Alps, respectively. Since $f_{\mathrm{NF}, \mathrm{EC}}$ values are often close to 0.5 (even slightly higher for some stations) this shows that also residential wood combustion contributes to a large extent to EC during winter-smog episodes in Switzerland. The sum of non-fossil OC and EC contributes on average $70 \pm 18$ and $79 \pm 10 \%$ to total carbon at stations north and south of the Alps, respectively, highlighting the importance of wood burning emissions from residential heating in Switzerland during winter-smog episodes. This is in agreement with recent studies which have shown that residential wood burning can be the dominating source of carbonaceous aerosols during the cold season in Europe.

The comparison between fossil $\mathrm{EC}\left(\mathrm{EC}_{\mathrm{F}}\right.$, only emitted as primary aerosol) and nitrogen oxides $\left(\mathrm{NO}_{\mathrm{x}}\right)$, which are mainly associated with traffic emissions, showed a good agreement whereas no correlation was observed between fossil $\mathrm{OC}\left(\mathrm{OC}_{\mathrm{F}}\right)$ and the two latter components, indicating that a considerable amount of $\mathrm{OC}_{\mathrm{F}}$ is secondary $\mathrm{OC}$ (SOC) formed from fossil precursors mainly emitted from traffic. Correlations between non-fossil $\mathrm{OC}\left(\mathrm{OC}_{\mathrm{NF}}\right)$ and $\mathrm{EC}\left(\mathrm{EC}_{\mathrm{NF}}\right)$ and the wood burning markers levoglucosan and water soluble potassium $\left(\mathrm{K}^{+}\right)$clearly show different slopes for stations north and south of the Alps suggesting different burning technologies in both regions.

The Supplement related to this article is available online at doi:10.5194/acp-14-13551-2014-supplement.
Acknowledgements. This work was funded by the Swiss Federal Office for the Environment (FOEN), inNet Monitoring AG, OSTLUFT, the country Liechtenstein and the Swiss cantons Basel-Stadt, Basel-Landschaft, Graubünden, St. Gallen, Solothurn, Valais, Uri and Ticino.

Edited by: N. M. Donahue

\section{References}

Andersson, A., Sheesley, R. J., Kruså, M., Johansson, C., and Gustafsson, Ö.: ${ }^{14} \mathrm{C}$-based source assessment of soot aerosols in Stockholm and the Swedish EMEP-Aspvreten regional background site, Atmos. Environ., 45, 215-222, doi:10.1016/j.atmosenv.2010.09.015, 2011.

BAG - Bundesamt für Gesundheit, Jahresberichte Umweltradioaktivität und Strahlendosen: Umweltradioaktivität und Strahlendosen in der Schweiz 2007, available at: http://www.bag.admin. ch/themen/strahlung/00043/00065/02239/index.html?lang=de (last access: 30 April 2014), 2008.

Barmpadimos, I., Hueglin, C., Keller, J., Henne, S., and Prévôt, A. S. H.: Influence of meteorology on $\mathrm{PM}_{10}$ trends and variability in Switzerland from 1991 to 2008, Atmos. Chem. Phys., 11, 18131835, doi:10.5194/acp-11-1813-2011, 2011.

Bernardoni, V., Calzolai, G., Chiari, M., Fedi, M., Lucarelli, F., Nava, S., Piazzalunga, A., Riccobono, F., Taccetti, F., Valli, G., and Vecchi, R.: Radiocarbon analysis on organic and elemental carbon in aerosol samples and source apportionment at an urban site in Northern Italy, J. Aerosol. Sci., 56, 88-99, doi:10.1016/j.jaerosci.2012.06.001, 2013.

Canonaco, F., Crippa, M., Slowik, J. G., Baltensperger, U., and Prévôt, A. S. H.: SoFi, an IGOR-based interface for the efficient use of the generalized multilinear engine (ME-2) for the source apportionment: ME-2 application to aerosol mass spectrometer data, Atmos. Meas. Tech., 6, 3649-3661, doi:10.5194/amt6-3649-2013, 2013.

Caseiro, A., Bauer, H., Schmidl, C., Pio, C. A., and Puxbaum, H.: Wood burning impact on $\mathrm{PM}_{10}$ in three Austrian regions, Atmos. Environ., 43, 2186-2195, doi:10.1016/j.atmosenv.2009.01.012, 2009.

Cavalli, F., Viana, M., Yttri, K. E., Genberg, J., and Putaud, J.-P.: Toward a standardised thermal-optical protocol for measuring atmospheric organic and elemental carbon: the EUSAAR protocol, Atmos. Meas. Tech., 3, 79-89, doi:10.5194/amt-3-79-2010, 2010.

Ceburnis, D., Garbaras, A., Szidat, S., Rinaldi, M., Fahrni, S., Perron, N., Wacker, L., Leinert, S., Remeikis, V., Facchini, M. C., Prévôt, A. S. H., Jennings, S. G., Ramonet, M., and O'Dowd, C. D.: Quantification of the carbonaceous matter origin in submicron marine aerosol by ${ }^{13} \mathrm{C}$ and ${ }^{14} \mathrm{C}$ isotope analysis, Atmos. Chem. Phys., 11, 8593-8606, doi:10.5194/acp-11-85932011, 2011.

Cercl'Air - Schweizerische Gesellschaft der LufthygieneFachleute: available at: http://www.cerclair.ch/cmsv2/index.php (last access: 30 April 2014), 2012.

Chow, J. C., Watson, J. G., Pritchett, L. C., Pierson, W. R., Frazier, C. A., and Purcell, R. G.: The dri thermal/optical reflectance carbon analysis system: description, evaluation and application 
in U.S. Air quality studies, Atmos. Environ. A-Gen., 27, 11851201, doi:10.1016/0960-1686(93)90245-t, 1993.

Chow, J. C., Watson, J. G., Crow, D., Lowenthal, D. H., and Merrifield, T.: Comparison of IMPROVE and NIOSH carbon measurements, Aerosol Sci. Technol., 34, 23-34, doi:10.1080/027868201300081923, 2001.

Dusek, U., Monaco, M., Prokopiou, M., Gongriep, F., Hitzenberger, R., Meijer, H. A. J., and Röckmann, T.: Evaluation of a twostep thermal method for separating organic and elemental carbon for radiocarbon analysis, Atmos. Meas. Tech., 7, 1943-1955, doi:10.5194/amt-7-1943-2014, 2014.

El Haddad, I., D’Anna, B., Temime-Roussel, B., Nicolas, M., Boreave, A., Favez, O., Voisin, D., Sciare, J., George, C., Jaffrezo, J.-L., Wortham, H., and Marchand, N.: Towards a better understanding of the origins, chemical composition and aging of oxygenated organic aerosols: case study of a Mediterranean industrialized environment, Marseille, Atmos. Chem. Phys., 13, 78757894, doi:10.5194/acp-13-7875-2013, 2013.

EMPA: Technischer Bericht zum Nationalen Beobachtungsnetz für Luftfremdstoffe (NABEL), Dübendorf, Switzerland, available at: http://www.empa.ch/nabel (last access: 9 December 2014), 2013.

Engling, G., Carrico, C. M., Kreidenweis, S. M., Collett Jr, J. L., Day, D. E., Malm, W. C., Lincoln, E., Min Hao, W., Iinuma, Y., and Herrmann, H.: Determination of levoglucosan in biomass combustion aerosol by high-performance anion-exchange chromatography with pulsed amperometric detection, Atmos. Environ., 40, Supplement 2, 299-311, doi:10.1016/j.atmosenv.2005.12.069, 2006.

Favez, O., El Haddad, I., Piot, C., Boréave, A., Abidi, E., Marchand, N., Jaffrezo, J.-L., Besombes, J.-L., Personnaz, M.-B., Sciare, J., Wortham, H., George, C., and D'Anna, B.: Inter-comparison of source apportionment models for the estimation of wood burning aerosols during wintertime in an Alpine city (Grenoble, France), Atmos. Chem. Phys., 10, 5295-5314, doi:10.5194/acp-10-52952010, 2010.

Gehrig, R. and Buchmann, B.: Characterising seasonal variations and spatial distribution of ambient $\mathrm{PM}_{10}$ and $\mathrm{PM}_{2.5}$ concentrations based on long-term Swiss monitoring data, Atmos. Environ., 37, 2571-2580, doi:10.1016/s1352-2310(03)00221-8, 2003.

Gehrig, R., Hueglin, C., Schwarzenbach, B., Seitz, T., and Buchmann, B.: A new method to link $\mathrm{PM}_{10}$ concentrations from automatic monitors to the manual gravimetric reference method according to EN12341, Atmos. Environ., 39, 2213-2223, doi:10.1016/j.atmosenv.2005.01.005, 2005.

Gelencsér, A.: Carbonaceous Aerosols, Springer, Dordrecht, 352 pp., ISBN:978-1-4020-2887-8, 2004.

Gelencsér, A., May, B., Simpson, D., Sánchez-Ochoa, A., KasperGiebl, A., Puxbaum, H., Caseiro, A., Pio, C., and Legrand, M.: Source apportionment of $\mathrm{PM}_{2.5}$ organic aerosol over Europe: Primary/secondary, natural/anthropogenic, and fossil/biogenic origin, J. Geophys. Res.-Atmos., 112, D23S04, doi:10.1029/2006JD008094, 2007.

Genberg, J., Hyder, M., Stenström, K., Bergström, R., Simpson, D., Fors, E. O., Jönsson, J. Å., and Swietlicki, E.: Source apportionment of carbonaceous aerosol in southern Sweden, Atmos. Chem. Phys., 11, 11387-11400, doi:10.5194/acp-1111387-2011, 2011
Gianini, M. F. D., Fischer, A., Gehrig, R., Ulrich, A., Wichser, A., Piot, C., Besombes, J. L., and Hueglin, C.: Comparative source apportionment of $\mathrm{PM}_{10}$ in Switzerland for 2008/2009 and 1998/1999 by Positive Matrix Factorisation, Atmos. Environ., 54, 149-158, doi:10.1016/j.atmosenv.2012.02.036, 2012.

Gianini, M. F. D., Piot, C., Herich, H., Besombes, J. L., Jaffrezo, J. L., and Hueglin, C.: Source apportionment of $\mathrm{PM}_{10}$, organic carbon and elemental carbon at Swiss sites: An intercomparison of different approaches, Sci. Total Environ., 454-455, 99-108, doi:10.1016/j.scitotenv.2013.02.043, 2013.

Gilardoni, S., Vignati, E., Cavalli, F., Putaud, J. P., Larsen, B. R., Karl, M., Stenström, K., Genberg, J., Henne, S., and Dentener, F.: Better constraints on sources of carbonaceous aerosols using a combined ${ }^{14} \mathrm{C}$ - macro tracer analysis in a European rural background site, Atmos. Chem. Phys., 11, 5685-5700, doi:10.5194/acp-11-5685-2011, 2011.

Glasius, M., la Cour, A., and Lohse, C.: Fossil and nonfossil carbon in fine particulate matter: A study of five European cities, J. Geophys. Res., 116, D11302, doi:10.1029/2011JD015646, 2011.

Hallquist, M., Wenger, J. C., Baltensperger, U., Rudich, Y., Simpson, D., Claeys, M., Dommen, J., Donahue, N. M., George, C., Goldstein, A. H., Hamilton, J. F., Herrmann, H., Hoffmann, T., Iinuma, Y., Jang, M., Jenkin, M. E., Jimenez, J. L., Kiendler-Scharr, A., Maenhaut, W., McFiggans, G., Mentel, Th. F., Monod, A., Prévôt, A. S. H., Seinfeld, J. H., Surratt, J. D., Szmigielski, R., and Wildt, J.: The formation, properties and impact of secondary organic aerosol: current and emerging issues, Atmos. Chem. Phys., 9, 5155-5236, doi:10.5194/acp-9-51552009, 2009.

Harrison, R. M., Beddows, D. C. S., Hu, L., and Yin, J.: Comparison of methods for evaluation of wood smoke and estimation of UK ambient concentrations, Atmos. Chem. Phys., 12, 82718283, doi:10.5194/acp-12-8271-2012, 2012.

Heal, M. R.: The application of carbon-14 analyses to the source apportionment of atmospheric carbonaceous particulate matter: a review, Anal. Bioanal. Chem., 406, 81-98, doi:10.1007/s00216013-7404-1, 2014.

Hennigan, C. J., Miracolo, M. A., Engelhart, G. J., May, A. A., Presto, A. A., Lee, T., Sullivan, A. P., McMeeking, G. R., Coe, H., Wold, C. E., Hao, W.-M., Gilman, J. B., Kuster, W. C., de Gouw, J., Schichtel, B. A., Collett Jr., J. L., Kreidenweis, S. M., and Robinson, A. L.: Chemical and physical transformations of organic aerosol from the photo-oxidation of open biomass burning emissions in an environmental chamber, Atmos. Chem. Phys., 11, 7669-7686, doi:10.5194/acp-11-7669-2011, 2011.

Herich, H., Hueglin, C., and Buchmann, B.: A 2.5 year's source apportionment study of black carbon from wood burning and fossil fuel combustion at urban and rural sites in Switzerland, Atmos. Meas. Tech., 4, 1409-1420, doi:10.5194/amt-4-1409-2011, 2011.

Herich, H., Gianini, M. F. D., Piot, C., Močnik, G., Jaffrezo, J. L., Besombes, J. L., Prévôt, A. S. H., and Hueglin, C.: Overview of the impact of wood burning emissions on carbonaceous aerosols and PM in large parts of the Alpine region, Atmos. Environ., 89, 64-75, doi:10.1016/j.atmosenv.2014.02.008, 2014.

Heringa, M. F., DeCarlo, P. F., Chirico, R., Tritscher, T., Dommen, J., Weingartner, E., Richter, R., Wehrle, G., Prévôt, A. S. H., and Baltensperger, U.: Investigations of primary and secondary particulate matter of different wood combustion appliances with 
a high-resolution time-of-flight aerosol mass spectrometer, Atmos. Chem. Phys., 11, 5945-5957, doi:10.5194/acp-11-59452011, 2011.

Hodzic, A., Jimenez, J. L., Prévôt, A. S. H., Szidat, S., Fast, J. D., and Madronich, S.: Can 3-D models explain the observed fractions of fossil and non-fossil carbon in and near Mexico City?, Atmos. Chem. Phys., 10, 10997-11016, doi:10.5194/acp10-10997-2010, 2010.

Huang, J., Kang, S., Shen, C., Cong, Z., Liu, K., Wang, W., and Liu, L.: Seasonal variations and sources of ambient fossil and biogenic-derived carbonaceous aerosols based on ${ }^{14} \mathrm{C}$ measurements in Lhasa, Tibet, Atmos. Res., 96, 553-559, doi:10.1016/j.atmosres.2010.01.003, 2010.

IPCC: Climate Change 2013: the physical science basis, Contribution of working group I to the fifth Assessment Report of the Intergovernmental Panel on Climate Change, edited by: Stocker, T. F., Qin, D., Plattner, G.-K., Tignor, M., Allen, S. K., Boschung, J., Nauels, A., Xia, Y., Bex, V., and Midgley, P. M., Cambridge University Press, Cambridge, United Kingdom and New York, NY, USA, 2013.

Jacobson, M. C., Hansson, H. C., Noone, K. J., and Charlson, R. J.: Organic atmospheric aerosols: Review and state of the science, Rev. Geophys., 38, 267-294, doi:10.1029/1998RG000045, 2000.

Jimenez, J. L., Canagaratna, M. R., Donahue, N. M., Prévôt, A. S. H., Zhang, Q., Kroll, J. H., DeCarlo, P. F., Allan, J. D., Coe, H., Ng, N. L., Aiken, A. C., Docherty, K. S., Ulbrich, I. M., Grieshop, A. P., Robinson, A. L., Duplissy, J., Smith, J. D., Wilson, K. R., Lanz, V. A., Hueglin, C., Sun, Y. L., Tian, J., Laaksonen, A., Raatikainen, T., Rautiainen, J., Vaattovaara, P., Ehn, M., Kulmala, M., Tomlinson, J. M., Collins, D. R., Cubison, M. J., E, Dunlea, J., Huffman, J. A., Onasch, T. B., Alfarra, M. R., Williams, P. I., Bower, K., Kondo, Y., Schneider, J., Drewnick, F., Borrmann, S., Weimer, S., Demerjian, K., Salcedo, D., Cottrell, L., Griffin, R., Takami, A., Miyoshi, T., Hatakeyama, S., Shimono, A., Sun, J. Y., Zhang, Y. M., Dzepina, K., Kimmel, J. R., Sueper, D., Jayne, J. T., Herndon, S. C., Trimborn, A. M., Williams, L. R., Wood, E. C., Middlebrook, A. M., Kolb, C. E., Baltensperger, U., and Worsnop, D. R.: Evolution of organic aerosols in the atmosphere, Science, 326, 1525-1529, doi:10.1126/science.1180353, 2009.

Johansson, L. S., Tullin, C., Leckner, B., and Sjövall, P.: Particle emissions from biomass combustion in small combustors, Biomass Bioenerg., 25, 435-446, doi:10.1016/S09619534(03)00036-9, 2003.

Kessler, S. H., Smith, J. D., Che, D. L., Worsnop, D. R., Wilson, K. R., and Kroll, J. H.: Chemical sinks of organic aerosol: Kinetics and products of the heterogeneous oxidation of erythritol and levoglucosan, Environ. Sci. Technol., 44, 7005-7010, doi:10.1021/es101465m, 2010.

Khalil, M. A. K. and Rasmussen, R. A.: Tracers of wood smoke, Atmos. Environ., 37, 1211-1222, doi:10.1016/S13522310(02)01014-2, 2003.

Lanz, V. A., Alfarra, M. R., Baltensperger, U., Buchmann, B., Hueglin, C., Szidat, S., Wehrli, M. N., Wacker, L., Weimer, S., Caseiro, A., Puxbaum, H., and Prévôt, A. S. H.: Source attribution of submicron organic aerosols during wintertime inversions by advanced factor analysis of aerosol mass spectra, Environ. Sci. Technol., 42, 214-220, doi:10.1021/es0707207, 2008.
Lanz, V. A., Prévôt, A. S. H., Alfarra, M. R., Weimer, S., Mohr, C., DeCarlo, P. F., Gianini, M. F. D., Hueglin, C., Schneider, J., Favez, O., D'Anna, B., George, C., and Baltensperger, U.: Characterization of aerosol chemical composition with aerosol mass spectrometry in Central Europe: an overview, Atmos. Chem. Phys., 10, 10453-10471, doi:10.5194/acp-10-10453-2010, 2010.

Larsen, B. R., Gilardoni, S., Stenström, K., Niedzialek, J., Jimenez, J., and Belis, C. A.: Sources for PM air pollution in the Po Plain, Italy: II. Probabilistic uncertainty characterization and sensitivity analysis of secondary and primary sources, Atmos. Environ., 50, 203-213, doi:10.1016/j.atmosenv.2011.12.038, 2012.

Lee, T., Sullivan, A. P., Mack, L., Jimenez, J. L., Kreidenweis, S. M., Onasch, T. B., Worsnop, D. R., Malm, W., Wold, C. E., Hao, W. M., and Collett, J. L.: Chemical smoke marker emissions during flaming and smoldering phases of laboratory open burning of wildland fuels, Aerosol Sci. Technol., 44, i-v, doi:10.1080/02786826.2010.499884, 2010.

Levin, I., Naegler, T., Kromer, B., Diehl, M., Francey, R. J., GomezPelaez, A. J., Steele, L. P., Wagenbach, D., Weller, R., and Worthy, D. E.: Observations and modelling of the global distribution and long-term trend of atmospheric ${ }^{14} \mathrm{CO}_{2}$, Tellus B, 62, 26-46, doi:10.1111/j.1600-0889.2009.00446.x, 2010.

Liu, D., Allan, J. D., Young, D. E., Coe, H., Beddows, D., Fleming, Z. L., Flynn, M. J., Gallagher, M. W., Harrison, R. M., Lee, J., Prevot, A. S. H., Taylor, J. W., Yin, J., Williams, P. I., and Zotter, P.: Size distribution, mixing state and source apportionment of black carbon aerosol in London during wintertime, Atmos. Chem. Phys., 14, 10061-10084, doi:10.5194/acp-14-100612014, 2014.

MeteoSwiss, Federal Office of Meteorology and Climatology: available at: http://www.meteoschweiz.admin.ch/web/en.html (last access: 30 April 2014), 2014.

Minguillón, M. C., Perron, N., Querol, X., Szidat, S., Fahrni, S. M., Alastuey, A., Jimenez, J. L., Mohr, C., Ortega, A. M., Day, D. A., Lanz, V. A., Wacker, L., Reche, C., Cusack, M., Amato, F., Kiss, G., Hoffer, A., Decesari, S., Moretti, F., Hillamo, R., Teinilä, K., Seco, R., Peñuelas, J., Metzger, A., Schallhart, S., Müller, M., Hansel, A., Burkhart, J. F., Baltensperger, U., and Prévôt, A. S. H.: Fossil versus contemporary sources of fine elemental and organic carbonaceous particulate matter during the DAURE campaign in Northeast Spain, Atmos. Chem. Phys., 11, 12067-12084, doi:10.5194/acp-11-12067-2011, 2011.

Mohn, J., Szidat, S., Fellner, J., Rechberger, H., Quartier, R., Buchmann, B., and Emmenegger, L.: Determination of biogenic and fossil $\mathrm{CO}_{2}$ emitted by waste incineration based on ${ }^{14} \mathrm{CO}_{2}$ and mass balances, Bioresource Technol., 99, 64716479, doi:10.1016/j.biortech.2007.11.042, 2008.

NIOSH: Elemental Carbon (Diesel Particulate): Method 5040, www.cdc.gov./niosh/nmam/pdfs/5040f3.pdf (last access: 30 April 2014), 1999.

Perron, N., Sandradewi, J., Alfarra, M. R., Lienemann, P., Gehrig, R., Kasper-Giebl, A., Lanz, V. A., Szidat, S., Ruff, M., Fahrni, S., Wacker, L., Baltensperger, U., and Prévôt, A. S. H.: Composition and sources of particulate matter in an industrialised Alpine valley, Atmos. Chem. Phys. Discuss., 10, 9391-9430, doi:10.5194/acpd-10-9391-2010, 2010.

Peterson, M. R. and Richards, M. H.: Thermal-optical transmittance analysis for organic, elemental, carbonate, total carbon, and OCX2 in $\mathrm{PM}_{2.5}$ by the EPA/NIOSH method, in: Proceed- 
ings, Symposium on Air Quality Measurement Methods and Technology-2002, edited by: Winegar, E. D. and Tropp, R. J., Air \& Waste Management Association, Pittsburgh, PA, 83-1-83-19, 2002.

Piazzalunga, A., Fermo, P., Bernardoni, V., Vecchi, R., Valli, G., and De Gregorio, M. A.: A simplified method for levoglucosan quantification in wintertime atmospheric particulate matter by high performance anion-exchange chromatography coupled with pulsed amperometric detection, Int. J. Environ. Anal. Chem., 90, 934-947, doi:10.1080/03067310903023619, 2010.

Piazzalunga, A., Bernardoni, V., Fermo, P., Valli, G., and Vecchi, R.: Technical Note: On the effect of water-soluble compounds removal on EC quantification by TOT analysis in urban aerosol samples, Atmos. Chem. Phys., 11, 10193-10203, doi:10.5194/acp-11-10193-2011, 2011a.

Piazzalunga, A., Belis, C., Bernardoni, V., Cazzuli, O., Fermo, P., Valli, G., and Vecchi, R.: Estimates of wood burning contribution to PM by the macro-tracer method using tailored emission factors, Atmos. Environ., 45, 6642-6649, doi:10.1016/j.atmosenv.2011.09.008, 2011b.

Piazzalunga, A., Bernardoni, V., Fermo, P., and Vecchi, R.: Optimisation of analytical procedures for the quantification of ionic and carbonaceous fractions in the atmospheric aerosol and applications to ambient samples, Anal. Bioanal. Chem., 405, 11231132, doi:10.1007/s00216-012-6433-5, 2013a.

Piazzalunga, A., Anzano, M., Collina, E., Lasagni, M., Lollobrigida, F., Pannocchia, A., Fermo, P., and Pitea, D.: Contribution of wood combustion to PAH and PCDD/F concentrations in two urban sites in Northern Italy, J. Aerosol. Sci., 56, 30-40, doi:10.1016/j.jaerosci.2012.07.005, 2013b.

Pope, C. A. and Dockery, D. W.: Health effects of fine particulate air pollution: Lines that connect, J. Air Waste Manage. Assoc., 56, 709-742, doi:10.1080/10473289.2006.10464485, 2006.

Pöschl, U.: Atmospheric aerosols: Composition, transformation, climate and health effects, Angew. Chem. Int. Edt., 44, 75207540, doi:10.1002/anie.200501122, 2005.

Putaud, J.-P., Raes, F., Van Dingenen, R., Brüggemann, E., Facchini, M. C., Decesari, S., Fuzzi, S., Gehrig, R., Hüglin, C., Laj, P., Lorbeer, G., Maenhaut, W., Mihalopoulos, N., Müller, K., Querol, X., Rodriguez, S., Schneider, J., Spindler, G., Tørseth, K., and Wiedensohler, A.: A European aerosol phenomenology2: chemical characteristics of particulate matter at kerbside, urban, rural and background sites in Europe, Atmos. Environ., 38, 2579-2595, doi:10.1016/j.atmosenv.2004.01.041, 2004.

Puxbaum, H., Caseiro, A., Sánchez-Ochoa, A., Kasper-Giebl, A., Claeys, M., Gelencsér, A., Legrand, M., Preunkert, S., and Pio, C.: Levoglucosan levels at background sites in Europe for assessing the impact of biomass combustion on the European aerosol background, J. Geophys. Res.-Atmos., 112, D23S05, doi:10.1029/2006JD008114, 2007.

Ruff, M., Wacker, L., Gaggeler, H. W., Suter, M., Synal, H. A., and Szidat, S.: A gas ion source for radiocarbon measurements at 200 kV, Radiocarbon, 49, 307-314, 2007.

Ruff, M., Szidat, S., Gäggeler, H. W., Suter, M., Synal, H. A., and Wacker, L.: Gaseous radiocarbon measurements of small samples, Nucl. Instr. Methods Phys. Res., Sec. B, 268, 790-794, doi:10.1016/j.nimb.2009.10.032, 2010.
Ruffieux, D., Nash, J., Jeannet, P., and Agnew, J. L.: The COST 720 temperature, humidity, and cloud profiling campaign: TUC, Meteorol. Z., 15, 5-10, doi:10.1127/0941-2948/2006/0095, 2006.

Sandradewi, J., Prévôt, A. S. H., Szidat, S., Perron, N., Alfarra, M. R., Lanz, V. A., Weingartner, E., and Baltensperger, U.: Using aerosol light absorption measurements for the quantitative determination of wood burning and traffic emission contributions to particulate matter, Environ. Sci. Technol., 42, 3316-3323, doi:10.1021/es702253m, 2008a.

Sandradewi, J., Prévôt, A. S. H., Alfarra, M. R., Szidat, S., Wehrli, M. N., Ruff, M., Weimer, S., Lanz, V. A., Weingartner, E., Perron, N., Caseiro, A., Kasper-Giebl, A., Puxbaum, H., Wacker, L., and Baltensperger, U.: Comparison of several wood smoke markers and source apportionment methods for wood burning particulate mass, Atmos. Chem. Phys. Discuss., 8, 8091-8118, doi:10.5194/acpd-8-8091-2008, 2008b.

Schauer, J. J., Kleeman, M. J., Cass, G. R., and Simoneit, B. R. T.: Measurement of emissions from air pollution sources. 1. $C_{1}$ through $\mathrm{C}_{29}$ organic compounds from meat charbroiling, Environ. Sci. Technol., 33, 1566-1577, doi:10.1021/es980076j, 1999.

Schauer, J. J., Kleeman, M. J., Cass, G. R., and Simoneit, B. R. T.: Measurement of emissions from air pollution sources. 3. $\mathrm{C}_{1}-\mathrm{C}_{29}$ organic compounds from fireplace combustion of wood, Environ. Sci. Technol., 35, 1716-1728, doi:10.1021/es001331e, 2001.

Schmid, H., Laskus, L., Abraham, H. J., Baltensperger, U., Lavanchy, V., Bizjak, M., Burba, P., Cachier, H., Crow, D., Chow, J., Gnauk, T., Even, A., ten Brink, H. M., Giesen, K.-P., Hitzenberger, R., Hueglin, C., Maenhaut, W., Pio, C., Carvalho, A., Putaud, J.-P., Toom-Sauntry, D., and Puxbaum, H.: Results of the "carbon conference" international aerosol carbon round robin test stage I, Atmos. Environ., 35, 2111-2121, 2001.

Schmidl, C., Marr, I. L., Caseiro, A., Kotianová, P., Berner, A., Bauer, H., Kasper-Giebl, A., and Puxbaum, H.: Chemical characterisation of fine particle emissions from wood stove combustion of common woods growing in midEuropean Alpine regions, Atmos. Environ., 42, 126-141, doi:10.1016/j.atmosenv.2007.09.028, 2008.

Schmidl, C., Luisser, M., Padouvas, E., Lasselsberger, L., Rzaca, M., Ramirez-Santa Cruz, C., Handler, M., Peng, G., Bauer, H., and Puxbaum, H.: Particulate and gaseous emissions from manually and automatically fired small scale combustion systems, Atmos. Environ., 45, 7443-7454, doi:10.1016/j.atmosenv.2011.05.006, 2011.

Simoneit, B. R. T., Schauer, J. J., Nolte, C. G., Oros, D. R., Elias, V. O., Fraser, M. P., Rogge, W. F., and Cass, G. R.: Levoglucosan, a tracer for cellulose in biomass burning and atmospheric particles, Atmos. Environ., 33, 173-182, doi:10.1016/S13522310(98)00145-9, 1999.

Steinbacher, M., Zellweger, C., Schwarzenbach, B., Bugmann, S., Buchmann, B., Ordóñez, C., Prévôt, A. S. H., and Hueglin, C.: Nitrogen oxide measurements at rural sites in Switzerland: Bias of conventional measurement techniques, J. Geophys. Res.Atmos., 112, D11307, doi:10.1029/2006JD007971, 2007.

Stuiver, M. and Polach, H. A.: Reporting of C-14 data - discussion, Radiocarbon, 19, 355-363, 1977.

Swiss Federal Statistical Office: Forstwirtschaft, available at: http: //www.bfs.admin.ch/bfs/portal/de/index/themen/07/04.html (last access: 30 April 2014), 2014. 
Synal, H. A., Stocker, M., and Suter, M.: MICADAS: A new compact radiocarbon AMS system, Nucl. Instr. Methods Phys. Res., Sec. B, 259, 7-13, doi:10.1016/j.nimb.2007.01.138, 2007.

Szidat, S.: Sources of Asian haze, Science, 323, 470-471, doi:10.1126/science.1169407, 2009.

Szidat, S., Jenk, T. M., Gäggeler, H. W., Synal, H. A., Fisseha, R., Baltensperger, U., Kalberer, M., Samburova, V., Wacker, L., Saurer, M., Schwikowski, M., and Hajdas, I.: Source apportionment of aerosols by ${ }^{14} \mathrm{C}$ measurements in different carbonaceous particle fractions, Radiocarbon, 46, 475-484, 2004.

Szidat, S., Jenk, T. M., Synal, H. A., Kalberer, M., Wacker, L., Hajdas, I., Kasper-Giebl, A., and Baltensperger, U.: Contributions of fossil fuel, biomass-burning, and biogenic emissions to carbonaceous aerosols in Zurich as traced by ${ }^{14} \mathrm{C}$, J. Geophys. Res.Atmos., 111, D07206, doi:10.1029/2005JD006590, 2006.

Szidat, S., Prévôt, A. S. H., Sandradewi, J., Alfarra, M. R., Synal, H.-A., Wacker, L., and Baltensperger, U.: Dominant impact of residential wood burning on particulate matter in Alpine valleys during winter, Geophys. Res. Lett., 34, L05820, doi:10.1029/2006GL028325, 2007.

Szidat, S., Ruff, M., Perron, N., Wacker, L., Synal, H.-A., Hallquist, M., Shannigrahi, A. S., Yttri, K. E., Dye, C., and Simpson, D.: Fossil and non-fossil sources of organic carbon (OC) and elemental carbon (EC) in Göteborg, Sweden, Atmos. Chem. Phys., 9, 1521-1535, doi:10.5194/acp-9-1521-2009, 2009.

Szidat, S., Bench, G., Bernardoni, V., Calzolai, G., Czimczik, C. I., Derendorp, L., Dusek, U., Elder, K., Fedi, M. E., Genberg, J., Gustafsson, O., Kirillova, E., Kondo, M., McNichol, A. P., Perron, N., Santos, G. M., Stenstrom, K., Swietlicki, E., Uchida, M., Vecchi, R., Wacker, L., Zhang, Y. L., and Prévôt, A. S. H.: Intercomparison of C-14 analysis of carbonaceous aerosols: exercise 2009, Radiocarbon, 56, 561-566, doi:10.2458/azu_js_rc.55.16314, 2013.

Szidat, S., Salazar, G. A., Vogel, E., Battaglia, M., Wacker, L., Synal, H.-A., and Türler, A.: ${ }^{14} \mathrm{C}$ analysis and sample preparation at the new Bern Laboratory for the Analysis of Radiocarbon with AMS (LARA), Radiocarbon, 56, 561-566, doi:10.2458/56.17457, 2014.

Tanner, R. L., Parkhurst, W. J., and McNichol, A. P.: Fossil sources of ambient aerosol carbon based on ${ }^{14} \mathrm{C}$ measurements, Aerosol Sci. Technol., 38, 133-139, 2004.

Turpin, B. J. and Lim, H. J.: Species contributions to PM2.5 mass concentrations: Revisiting common assumptions for estimating organic mass, Aerosol Sci. Technol., 35, 602-610, doi:10.1080/02786820152051454, 2001.

Valmari, T., Kauppinen, E. I., Kurkela, J., Jokiniemi, J. K., Sfiris, G., and Revitzer, H.: Fly ash formation and deposition during fluidized bed combustion of willow, J. Aerosol. Sci., 29, 445459, doi:10.1016/S0021-8502(97)10021-0, 1998.
Viana, M., Chi, X., Maenhaut, W., Cafmeyer, J., Querol, X., Alastuey, A., Mikuška, P., and Večeřa, Z.: Influence of sampling artefacts on measured PM, OC, and EC levels in carbonaceous aerosols in an urban area, Aerosol Sci. Technol., 40, 107-117, doi:10.1080/02786820500484388, 2006.

Viana, M., Maenhaut, W., ten Brink, H. M., Chi, X., Weijers, E., Querol, X., Alastuey, A., Mikuška, P., and Večeřa, Z.: Comparative analysis of organic and elemental carbon concentrations in carbonaceous aerosols in three European cities, Atmos. Environ., 41, 5972-5983, doi:10.1016/j.atmosenv.2007.03.035, 2007.

Wacker, L., Christl, M., and Synal, H. A.: Bats: A new tool for AMS data reduction, Nucl. Instr. Methods Phys. Res., Sec. B, 268, 976-979, doi:10.1016/j.nimb.2009.10.078, 2010.

Wacker, L., Fahrni, S. M., Hajdas, I., Molnar, M., Synal, H. A., Szidat, S., and Zhang, Y. L.: A versatile gas interface for routine radiocarbon analysis with a gas ion source, Nucl. Instr. Methods Phys. Res., Sec. B, 294, 315-319, doi:10.1016/j.nimb.2012.02.009, 2013.

WHO: Air Quality Guidelines for Particulate Matter, Ozone, Nitrogen Dioxide and Sulfur Dioxide, Global Update 2005, Summary of Risk Assessment, World Health Organization, document WHO/SDE/PHE/OEH/06.02, Geneva, 2006.

Zapf, A., Nesje, A., Szidat, S., Wacker, L., and Schwikowski, M.: C-14 measurements of ice samples from the Juvfonne ice tunnel, Jotunheimen, southern Norway-validation of a C14 dating technique for glacier ice, Radiocarbon, 55, 571-578, doi:10.2458/azu_js_rc.55.16320, 2013.

Zencak, Z., Elmquist, M., and Gustafsson, O.: Quantification and radiocarbon source apportionment of black carbon in atmospheric aerosols using the CTO-375 method, Atmos. Environ., 41, 7895-7906, doi:10.1016/j.atmosenv.2007.06.006, 2007.

Zhang, Y. L., Perron, N., Ciobanu, V. G., Zotter, P., Minguillón, M. C., Wacker, L., Prévôt, A. S. H., Baltensperger, U., and Szidat, S.: On the isolation of OC and EC and the optimal strategy of radiocarbon-based source apportionment of carbonaceous aerosols, Atmos. Chem. Phys., 12, 10841-10856, doi:10.5194/acp-12-10841-2012, 2012.

Zhang, Y. L., Li, J., Zhang, G., Zotter, P., Huang, R. J., Tang, J. H., Wacker, L., Prévôt, A. S. H., and Szidat, S.: Radiocarbonbased source apportionment of carbonaceous aerosols at a regional background site on Hainan Island, South China, Environ. Sci. Technol., 48, 2651-2659, doi:10.1021/es4050852, 2014.

Zotter, P., Zhang, Y. L., El-Haddad, I., Ciobanu, V. G., Daellenbach, K. R., Salazar, G. A., Wacker, L., Herich, H., Hueglin, C., Baltensperger, U., Szidat, S., and Prévôt, A. S. H.: Radiocarbon analysis of elemental and organic carbon in Switzerland during winter-smog episodes from 2008 to 2012 - Part 2: Daily, seasonal and yearly variability, Atmos. Chem. Phys. Discuss., in preparation, 2014. 